ISBN 978-623-6833-98-8 (PDF)

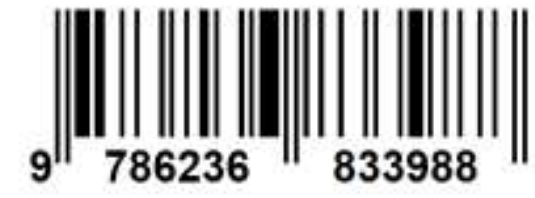

\title{
AKUNTANSI ASET, LIABILITAS DAN EKUITAS
}

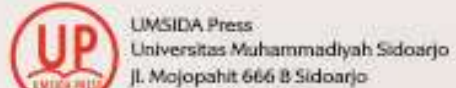
Sidoarja Jawa Timur
}

\section{Eny Maryanti, SE,,MA.}

Heri Widodo, SE., M.Si.AK.

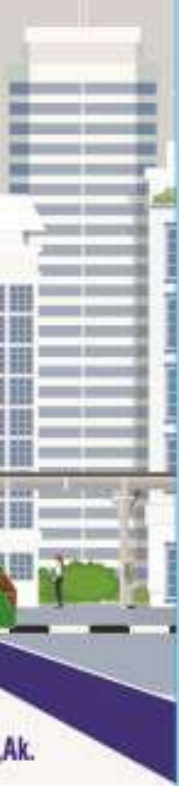




\section{BUKU AJAR AKUNTANSI ASET, LIABILITAS DAN EKUITAS \\ Penulis:}

Eny Maryanti, SE.,MA

Heri Widodo, SE.,M.Si

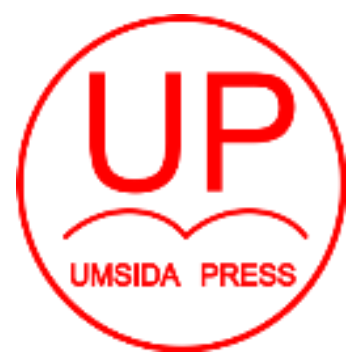

Diterbitkan oleh UMSIDA PRESS

\section{UNIVERSITAS MUHAMMADIYAH SIDOARJO \\ 2020}




\section{BUKU AJAR AKUNTANSI}

\section{ASET, LIABILITAS, DAN EKUITAS}

\section{Penulis:}

Eny Maryanti, SE.,M.A

Hery Widodo, SE, M.Si

\section{ISBN :}

978-623-6833-98-8

\section{Editor:}

Dr.Sigit Hermawan, SE.,M.Si

\section{Design Sampul dan Tata Letak:}

Mochammad Nashrullah, S.Pd.

Amy Yoga Prajati, S.Kom.

\section{Penerbit:}

UMSIDA Press

Anggota IKAPI No. 218/Anggota Luar Biasa/JTI/2019

Anggota APPTI No. 0020181092017

\section{Redaksi}

Universitas Muhammadiyah Sidoarjo

Jl. Mojopahit No 666B

Sidoarjo, Jawa Timur

Cetakan Pertama, September 2020

CHak Cipta dilindungi undang undang

Dilarang memperbanyak karya tulis ini dengan sengaja, tanpa ijin tertulis dari penerbit. 


\section{KATA PENGANTAR}

Buku Akuntansi Aset Liabilitas dan Ekuitas merupakan buku pengabungan Akuntansi Keuangan Menengah 1 dan Akuntansi Keuangan Menengah 2. Tujuan utama buku ini untuk membantu mahasiswa memahami penerapan PSAK berbasis IFRS pada penerapan pelaporan keuangan perusahaan. Bukuini dilengkapi dengan contoh soal sehingga akan membantu mahasiswa dalam memahami materi atas konsep yang diberikan dalambuku ini. Mahasiswa bisa mengaplikasikan akuntansi keuangan dalam dunia praktik. Kelebihan buku ini pada pemberian ilustrasi dan penjelasan yang mendalam mengenai konsep perlakuan, penyajian, pengakuan pada laporan keuangan yang mengacu pada PSAK yang berbasis IFRS.

Latihan-latihan yang banyak di dalam tiap bab sangat membantu mahasiswa dalam memahami materi, buku ini dijuga didukung dengan latihan soal dan jawaban sehingga mahasiswa bisa meningkatkan pemahaman mengenai Akuntansi Aset, Liabilitas dan Ekuitas.

September 2020

Tim Penulis 


\section{DAFTAR ISI}

\section{BAB 1 AKUNTANSI KEUANGAN DAN STANDAR AKUNTANSI}
A. Akuntansi, Laporan Keuangan
B. Akuntansi Keuangan dan Akuntansi Manajemen..............6

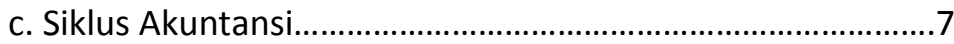

\section{BAB 2 KERANGKA KERJA KONSEPTUAL}
A. Kerangka Keja Konseptual .14
B. Karakteristik kualitatif dari Informasi Akuntansi.......... 16
C. Pengambil Keputusan...................................................17

\section{BAB 3 SISTEM INFORMASI AKUNTANSI}
A. Debet dan Kredit .24
B. Persamaan Dasar Akuntansi. .25
C. Laporan Keuangan .29

\section{BAB 4 LAPORAN LABA RUGI}

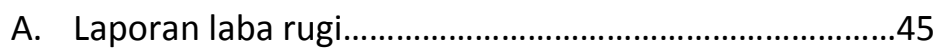


B. Format Laporan laba rugi..............................................46

C. Bentuk Laporan laba rugi.............................................47

\section{BAB 5 AKUNTANSI DAN NILAI WAKTU DARI UANG}
A. Konsep dari Nilai Waktu Dasar. .72
B. Nilai Masa Depan dari Jumlah Tunggal 77
C. Nilai Masa depan dari anuitas .80

\section{BAB 6 KAS DAN PIUTANG}
A. Kas .88
B. Piutang .90
C. Wesel Tagih. .92

\section{BAB 7 Penilaian Persediaan}
A. Klasifikasi dan pengendalian persediaan.........................100
B. Perbedaan system perpetual dan periodik.. .102

\section{DAFTAR PUSTAKA}

BIODATA PENULIS 


\section{BATANG TUBUH DAN}

\section{SUB-CAPAIAN PEMBELAJARAN MATA KULIAH}

\begin{tabular}{|c|c|}
\hline BAB & Sub Capaian Pembelajaran Mata Kuliah \\
\hline 1 & $\begin{array}{l}\text { 1. Menjelaskan akuntansi dan laporan keuangan } \\
\text { 2. Menjelaskan akuntansi dalam alokasi sumber daya } \\
\text { 3. Menjelaskan standard akuntansi }\end{array}$ \\
\hline 2 & $\begin{array}{l}\text { 1. Menjelaskan kerangka dasar penyajian dan } \\
\text { penyusunan laporan keuangan } \\
\text { 2. Memahami Tujuan Pelaporan Keuanga } \\
\text { 3. Mengidentifikasi Karakteristik kualitatif dari } \\
\text { informasi akuntansi } \\
\text { 4. Mengetahui unsur-unsur dasar dalam laporan } \\
\text { keuangan }\end{array}$ \\
\hline 3 & $\begin{array}{l}\text { 1. Memahami dasar akuntansi } \\
\text { 2. Memahami mengenai aturan berpasangan } \\
\text { 3. Memahami siklus akuntansi } \\
\text { 4. Membuat transaksi pada jurnal, buku besar dan } \\
\text { neraca saldo } \\
\text { 5. Memahami ayat jurnal penyesuaian }\end{array}$ \\
\hline 4 & $\begin{array}{l}\text { 1. Memahami fungsi dan Keterbatasan Laba/rugi } \\
\text { 2. Memahami kualitas laba } \\
\text { 3. Membuat laporan laba ditahan }\end{array}$ \\
\hline 5 & $\begin{array}{l}\text { 1. Membandingkan bunga majemuk dan bunga } \\
\text { sederhana } \\
\text { 2. Memahami soal nilai masa depan dan nilai }\end{array}$ \\
\hline
\end{tabular}




\begin{tabular}{|c|c|c|}
\hline & & $\begin{array}{l}\text { sekarang } \\
\text { Memahami soal nilai sekarang dari anuitas biasa } \\
\text { dan jatuh tempo }\end{array}$ \\
\hline 6 & & $\begin{array}{l}\text { Menjelaskan tentang kas } \\
\text { Menjelaskan tentang piutang } \\
\text { Menjelaskan akuntansi dalam alokasi sumber daya }\end{array}$ \\
\hline 7 & & $\begin{array}{l}\text { Menjelaskan persediaan } \\
\text { Memahami metode persediaan }\end{array}$ \\
\hline
\end{tabular}




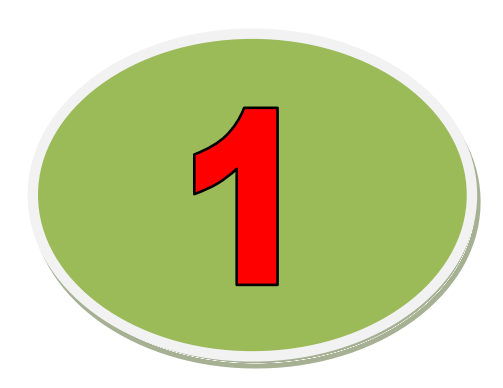

\section{AKUNTANSI KEUANGAN DAN} STANDARD KEUANGAN

TUJUAN PEMBELAJARAN

Setelah mempelajari bab ini, Anda diharapkan mampu:

1. Menjelaskan akuntansi dan laporan keuangan

2. Menjelaskan akuntansi dalam alokasi sumber daya

3. Menjelaskan standard akuntansi 


\section{BAB I}

\section{( AKUNTANSI KEUANGAN DAN STANDAR AKUNTANSI )}

\section{A. Pendahuluan}

Akuntansi merupakan ilmu yang penting karena mempunyai peran untuk membantu perusahaan, investor, pemerintah dan organisasi untuk pengambilan keputusan dengan menggunakaan sumber daya yang dimiliki oleh entitas tersebut. Pengambilan keputusan yang tepat diharapkan bisa meningkatkan kinerja perusahaan, namun untuk membuat laporan keuangan, seorang akuntan harus memahami kerangka prosedur yaitu Pernyataan Standard Akuntansi Keuangan (PSAK)

\section{B. Akuntansi, Laporan Keuangan Dan Pelaporan Keuangan}

Pada sebuah entitas akuntansi merupakan memegang peranan penting, akuntansi memberikan informasi mengenai kinerja keuangan perusahaan dalam suatu periode. Informasi akuntansi digunakan oleh pihak internal maupun eksternal perusahaan. Pengguna informasi tersebut membutuhkan informasi akuntansi untuk membuat sebuah keputusan yang terkait

Perusahaan ingin mengetahui perkembangan perusahaannya dari waktu ke waktu. Beberapa pertanyaanpertanyaan berikut merupakan pertanyaan yang 
berhubungan dengan pertanyaan mengenai perkembangan perusahaan:

1. Berapakah jumlah piutang perusahaan dan siapa debiturnya?

2. Berapakah jumlah utang perusahaan dan siapa krediturnya?

3. Debitur-debitur mana saja yang tidak tepat dalam memenuhi kewajiban membayar utangnya?

4. Perusahaan mengalami laba atau rugi dan berapa besarnya laba atau ruginya?

5. Berapa jumlah pajak yang harus dibayar oleh perusahaan?

Pertanyaan-pertanyaan tersebut dapat diperoleh jawabanya kalau perusahaan mengerjakan akuntansi. Tujuan utama akuntansi adalah memberi informasi keuangan. Definisi akuntansi yang diberikan oleh the American Accounting Association (AAA) sebagai berikut: Accounting is the process of identifiying, measuring and communicating economic information to permit informed judgement and decisions by user of the information. Artinya akuntansi ialah proses pengidentifikasian, pengukuran dan pengkomunikasian informasi untuk memungkinkan memperoleh pertimbangan dan keputusan yang tepat bagi para pemakai informasi tersebut.

Akuntansi keuangan merupakan sebuah rangkaian proses yang hasil akhirnya adalah laporan keuangan yang digunakan oleh pihak-pihak yang mempunyai kepentingan. 
Berdasarkan pengertian diatas, terdiri atas empat hal mengenai pengertian akuntansi yaitu:

1. Masukan (input) merupakan suatu transaksi yang dibukukan dan ada buktinya. Pencatatan transaksi dicatat berdasarkan historis dan secara sistematis selama peride tertentu, tiap catatan harus ditunjang dengan dokumen seperti faktur, kuitansi dan lainlain.

2. Proses merupakan rangkaian kegiatan dari transaksi yang diringkas menjadi laporan.Transaksi-transaski yang sudah dicatat itu dikelompokan menurut jenisnya kemudian diringkas pada sebuah daftar

3. Output (keluaran) merupakan informasi keuangan yang menjadi sebuah laporan keuangan

4. Pengguna Laporan Keuangan merupakan pihak yang yang mengunakan laporan keuangan untuk pengambilan keputusan. Pengguna informasi akuntansi ini dikelompokan menjadi dua kategori yaitu:

A. Pihak Internal merupakan pihak yang ikut dalam operasional perusahaan seperti: Pihak manajemen (direktur, manajer keuangan dan direktur operasional), karyawan.

B. Pihak Eksternal merupakan pihak yang tidak ikut dalam operasional perusahaan seperti: 
investor, kreditur, pemerintah, supplier, BAPEPAM.

GAMBAR 1.1

Informasi Akuntansi dan Pihak-pihak Berkepentingan Pada Suatu Perusahaan

Mengidentifikasi

Pihak-pihak yang

berkepentingan

Internal: Pemilik, manajer, karyawan

Eksternal:

Pelanggan,

Kreditor,

Pemerintah

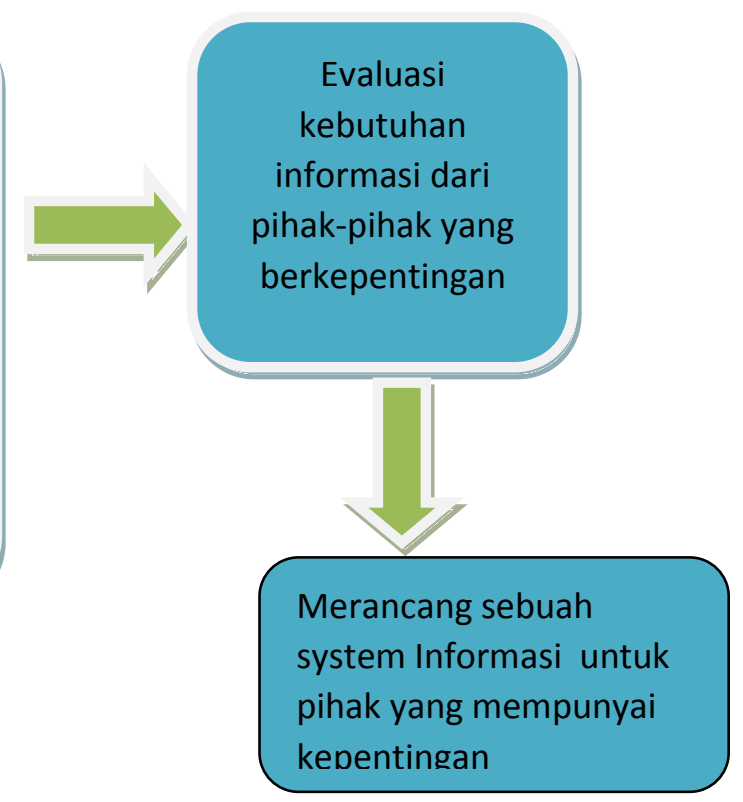


Menyiapkan Laporan keuangan untuk pihakpihak berkepentingan

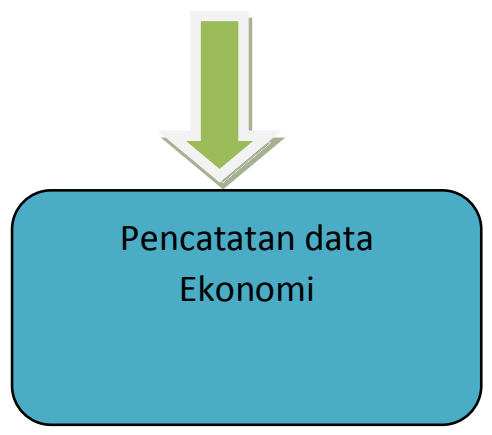

C. Akuntansi Keuangan dan Akuntansi Manajemen

Pihak-Pihak yang memerlukan informasi akuntansi ada pihak intern dan pihak ekstern maka akuntansi dibagi menjadi :

1. Akuntansi Keuangan

Merupakan akuntansi yang mempunyai tujuan untuk melakukan pencatatan transaksi-transaksi keuangan dan menyusun laporan keuangan secara periodik. Laporan keuangan dibuat untuk memenuhi kepentingan umum di luar perusahaan untuk pengambilan keputusan, seperti bank, pemerintah. 
2. Akuntansi Manajemen

Merupakan akuntansi yang mempunyai tujuan utama memberikan informasi kepadapihakp-pihak intern perusahaan seperti manajer atau pengelola perusahaan untuk pengambilan keputusan. Akuntansi manajemen berkaitan dengan perencanaan, pengambilan keputusan dan pengawasan.

\section{Siklus Akuntansi}

Gambar 1.2

Siklus Akuntansi

\section{Input}

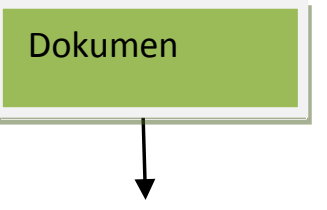




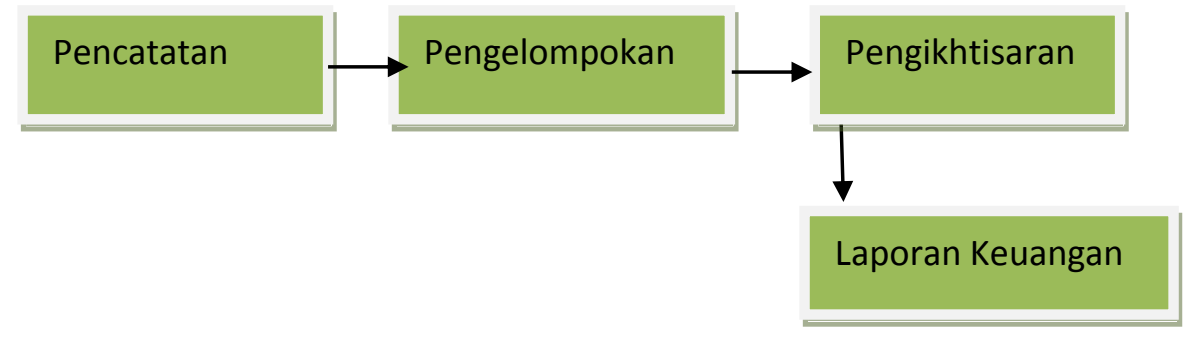

Tahapan kegiatan pada gambar 1.2 dimulai dari penyediaan dokumen sumber dari transaksi (sebagai input) sampai pembuatan laporan keuangan (output).Laporan keuangan merupakan hasil akhir dari proses akuntansi yang bisa digunakan sebagai alat untuk komunikasi data keuangan atau memberikan informasi mengenai aktivitas perusahaan. Tujuan laporan keuangan adalah menyajikan data atau informasi keuangan secara wajar dan sesuai dengan prinsip akuntansi yang berlaku secara umum. Laporan keuangan merupakan sarana pengomunikasian informasi keuangan utama kepada pihak-pihak diluar perusahaan. Laporan keuangan ( financial statements) yang sering disajikan adalah:

1. Neraca

Merupakan laporan mengenai posisi aktiva, kewajiban dan ekuitas perusahaan.

2. Laporan laba- rugi

Merupakan laporan tentang pendapatan dan beban perusahaan pada suatu periode, yang akhirnya memberikan informasi mengenai hasil usaha perusahaan. Jika selisish pendapatan 
lebih besar daripada beban maka akan terjadi laba dan sebaliknya.

\section{Pelaporan keuangan}

Pelaporan keuangan harus bertujuan menyediakan informasi yang :

1. Memberikan informasi yang berguna untuk membuat keputusan bagi pihak pengguna laporan keuangan.

2. Memberikan informasi menggenai pertanggungjawaban atau kinerja manajemen

3. Memberikan informasi mengenai sumber daya ekonomi dari sebuah perusahaan.

4. Memberikan proyeksi keuangan entitas dimasa depan

\section{E. Akuntansi dan alokasi modal}

Sumber daya yang terbatas membuat perusahaan menggunakannya secara efektif dan efisien, hal tersebut akan menentukan apakah perusahaan bisa berkembang atau tidak. Seorang akuntan harus dengan seksama menguasai semua pengetahuan yang berhubungan dengan akuntansi, sehingga akuntan mampu mengukur kinerja perusahaan secara tepat, dan membuat penafsiran-penafsiran laporan keuangan. Sebagai contoh dengan informasi keuangan yang memiliki kualitas maka akan membantu investor dalam menganalisa sebuah perusahaan yang akan dibeli sahamnya. Dengan membandingkan laporan keuangan antara perusahaan akan membantu investor dalam mengambil keputusan akan membeli perusahaan yang mana. 
Kreditur dan investor merupakan sumber daya karena sebagai pemilik dana, investor akan memilah-milah investasi pada sebuah perusahaan yang akan memberikan tingkat pengembalian yang tinggi. Kreditur juga akan memilah-milah perusahaan yang layak diberikan pinjaman yang mempunyai kemampuan untuk mengembalikan dana kreditur dengan waktu yang telah ditentukan.

\section{F. Standar Akuntansi Keuangan}

Standar merupakan pedoman dalam menyusun laporan keuangan sehingga laporan keuangan memili keseragaman antar entitas, hal tersebut mempermudah pihak manajmen untuk membuat laporan keuangan karena standar memberikan ketentuan cara penyusuanan tersebut. Terdiir dari dua standard yang diadopsi oleh dunia yaitu IFRS (International Financial Reporting Standard) dan GAAP ( Generally Accapted Accounting Principles). Standard Akuntansi yang berlaku di Indonesia terdiri dari lima standard yaitu

1. Standar Akuntansi Keuangan (SAK) merupakan standar yang digunakan untuk entitas yang terdaftar atau dalam proses pendaftaran di pasar modal. Standard ini di Indonesia mengadopsi secara penuh IFRS pada tahun 2012.

2. Standard Akuntansi Keuangan Entitas Tanpa Akuntanbilitas Publik ( SAK ETAP) merupakan standard yang digunakan oleh entitas yang tidak memiliki akuntanbilitas public

3. Standard Akuntansi Syariah meruapakan standard yang digunakan oleh entitas yang memiliki dasar syariah. 
4. Standard Akuntansi Pemerintah (SAP) merupakan standard akuntansi yang digunakan oleh instansi pemerintah daerah dan pusat.

5. Standard Akuntansi EMKM merupakan standard akuntansi yang digunakan oleh entitas EMKM

\section{G. Kesimpulan}

Akuntansi keuangan merupakan sebuah rangkaian proses yang hasil akhirnya adalah laporan keuangan yang digunakan oleh pihakpihak yang mempunyai kepentingan. Berdasarkan pengertian diatas, terdiri atas empat hal mengenai pengertian akuntansi yaitu: Masukan (input) merupakan suatu transaksi yang dibukukan dan ada buktinya. Pencatatan transaksi dicatat berdasarkan historis dan secara sistematis selama peride tertentu, tiap catatan harus ditunjang dengan dokumen seperti faktur, kuitansi dan lain-lain. Proses merupakan rangkaian kegiatan dari transaksi yang diringkas menjadi laporan.Transaksi-transaski yang sudah dicatat itu dikelompokan menurut jenisnya kemudian diringkas pada sebuah daftar. Output (keluaran) merupakan informasi keuangan yang menjadi sebuah laporan keuangan. Pengguna Laporan Keuangan merupakan pihak yang yang mengunakan laporan keuangan untuk pengambilan keputusan. Pengguna informasi akuntansi ini dikelompokan menjadi dua kategori yaitu: Pihak Internal merupakan pihak yang ikut dalam operasional perusahaan seperti: Pihak manajemen (direktur, manajer keuangan dan direktur operasional), karyawan. Pihak Eksternal merupakan pihak yang tidak ikut dalam operasional perusahaan seperti: investor, kreditur, pemerintah, supplier, BAPEPAM. Standard Akuntansi yang berlaku di Indonesia terdiri dari lima standard yaitu :Standar Akuntansi Keuangan (SAK) merupakan standar yang digunakan untuk entitas yang terdaftar atau dalam proses pendaftaran di pasar modal. 
Standard ini di Indonesia mengadopsi secara penuh IFRS pada tahun 2012. Standard Akuntansi Keuangan Entitas Tanpa Akuntanbilitas Publik ( SAK ETAP) merupakan standard yang digunakan oleh entitas yang tidak memiliki akuntanbilitas public. Standard Akuntansi Syariah meruapakan standard yang digunakan oleh entitas yang memiliki dasar syariah. Standard Akuntansi Pemerintah (SAP) merupakan standard akuntansi yang digunakan oleh instansi pemerintah daerah dan pusat. Standard Akuntansi EMKM merupakan standard akuntansi yang digunakan oleh entitas EMKM

\section{SOAL}

1. Jelaskan apa yang dimaksud akuntansi?

2. Apakah yang dimaksud dengan transaksi-transaksi keuangan?

3. Sebutkan dan Jelaskan tujuan laporan keuangan!

4. Sebutkan lima standard akuntansi yang ada di Indonesia!

5. Sebutkan dan jelaskan lima laporan keuangan menurut PSAK!

\section{Daftar Pustaka}

Keiso, Donald E. Weygandt, Jerry J. Warfield, Terry D. 2007. Akuntansi Intermediate. Penerbit Erlangga. Jakarta.

Martani, Dwi. Dkk. 2016. Akuntansi Keuangan Menengah. Salemba Empat. Jakarta 
Niswonger, C. Rollin. Warren, Carls S. Reeve, James M. 1999.

Prinsip-Prinsip Akuntansi Edisi 19. Penerbit Erlangga. Jakarta

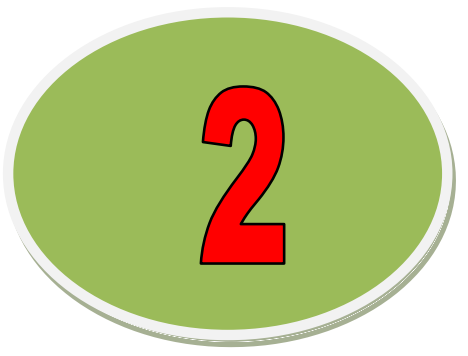




\section{Kerang|ka Kerja}

\section{Konseptual}

TUJUAN PEMBELAJARAN

Setelah mempelajari bab ini, Anda diharapkan mampu:

1. Menjelaskan kerangka dasar penyajian dan penyusunan laporan keuangan

2. Memahami Tujuan Pelaporan Keuanga

3. Mengidentifikasi Karakteristik kualitatif dari informasi akuntansi

4. Mengetahui unsur-unsur dasar dalam laporan keuangan

\section{BAB II}

\section{( KERANGKA KERJA KONSEPTUAL YANG MENDASARI AKUNTANSI KEUANGAN )}

\section{A. Pendahuluan}

Pemakai laporan keuangan ingin laporan keuangan yang dihasilkan mengandung informasi yang bisa 
diandalkan dan relevan. Oleh karena itu akuntan membutuhkan kerangka kerja konseptual untuk pedoman akuntansi.

\section{B. Kerangka Kerja Konseptual}

Kerangka kerja konseptual merupakan kerangka dasar penyajian dan penyusunan laporan keuangan, merupakan konsep fundamental keuangan yang menjadi landasan bagi penetapan standard. Kerangka konseptual ini menjadi pedoman untuk menyusun sebuah standard dan menjadi kunci dalam menyelesaikan permasalahan akuntansi yang mungkin belum ada dalam standard yang sudah ada.

\section{Tujuan Kerangka Konseptual}

Kerangka konseptual bertujuan untuk:

1. Menyusun standard akuntansi

2. Meningkatkan pemahaman pengguna laporan keuangan

3. Menaikan daya banding antar laporan keuangan perusahaan

4. Memberika solusi terhdap permasalahanpermasalahan akuntansi karena mengacu kepada teori fundamental

5. Para pengguna dalam menginterprestasikan informasi dalam laporan keuangan 
6. Membantu auditor dalam memberikan pendapat mengenai apakah laporan keuangan sesuai dengan prinsip akuntansi yang berlaku umum.

Kerangka konseptual menurut PSAK yaitu:

1. Tujuan laporan keuangan

2. Karakteristik kualitatif informasi keuangan yang berguna;

3. Definisi, pengakuan, dan pengukuran unsur-unsur yang membentuk laporan keuangan;

4. Konsep modal .dan pemeliharaan modal.

Kerangka konseptual merupakan fundamental dalam menyusun laporan keuangan, kerangka konseptual berlaku untuk semua jenis entitas baik sector swasta maupun sector publik.

\section{Tujuan Dasar}

Tujuan pelaporan keuangan yaitu:

1. Memberikan informasi yang berguna bagi pengambilan keputusan

2. Membantu kreditor dan investor dalam memprediksi arus kas dimasa yang akan datang

3. Memberikan informasi tentang sumber daya entitas 


\section{Karakteristik kualitatif dari Informasi Akuntansi}

Laporan Keuangan berisi informasi kuantitatif, yang berisikan informasi keuangan agar informasi tersebut bermanfaat bagi pengguna informasi tersebut maka harus memenuhi karakteristik kualitatif. Ada Empat karakteristik kualitatif yaitu:

1. Dapat dipahami

Laporan keuangan harus bisa dipahami oleh para pengguna laporan keuangan agar bisa digunakan untuk mengambil keputusan.

2. Relevan

Informasi dikatakan relevan jika informasi yang disajikan pada laporan keuangan berpengaruh terhadap keputusan perusahaan. Agar relevan, informasi akuntansi harus membuat perbedaan dalam sebuah keputusan. Jika tidak mempengaruhi keputusan, maka informasi tersebut dikatakan tidak relevan dengan keputusan yang diambil.

3. Keandalan

Informasi disebut andal jika informasi yang disajikan bebas dari kesalahan material, tidak menyesatkan dan disajikan secara wajar. Informasi akuntansi dianggap handal jika dapat diverivikasi, disajikan secara tepat serat bebas dari kesalahan dan bias. 
Daya uji (verifiability) ditunjukkan ketika pengukurpengukur independen, dengan menggunakan metode pengukuran yang sama, mendapat hasil yang serupa. Ketepatan penyajian (representational faithfullness) berarti bahwa angka-angka dan penjelasan dalam laporan keuangan mewakili apa yang beetul-betul ada dan terjadi. Netralitas (neutrality) berarti informasi tidak berpihak pada kepentingan tertentu

4. Kendala

Manfaat yang dihasilkan oleh informasi harus lebih besar daripada biaya yang dikeluarkan.

D. Pengambil keputusan (pemakai) dan kemampuan memahami

\section{Unsur-Unsur Dasar}

Salah satu aspek penting dalam pengembangan struktur teoritis adalah unsur-unsur dasar Unsur-unsur tersebut adalah:

1. Aktiva

Aktiva merupakan suatu sumber daya yang bisa memberikan manfaat di masa yang akan datang.

2. Kewajiban

Kewajiban merupakan kegiatan ekonomi dimasa depan berupa pengorbanan 


\section{Ekuitas}

Ekuitas merupakan selisih antara aktiva dan kewajiban perusahaan atau entitas.

4. Investasi

Investasi merupakan kegiatan yang mempunyai nilai untuk menaikan aktiva bersih atau untuk mendapatkan keuntungan di masa yang akan datang.

5. Dividen

Pembagian laba dilakukan jika perusahaan mendapatkan laba dari operasional perusahaan selama satu periode, pembagian laba tersebut diberikan kepada pemegang saham yang disebut deviden.

6. Laba/Rugi Komprehensif

Aktivitas perusahaan akan mengakibatkan laba/rugi yang disebut dengan laba/rugi komprehensif.

7. Pendapatan

Pendapatan adalah peningkatan aktiva atau adanya kas masuk dari kegiatan perusahaan dalam satu periode.

8. Beban

Beban adalah pengurangan aktiva atau adanya kas keluar karena adanya suatu kewajiban pada satu periode.

9. Keuntungan

Keuntungan merupakan selisih lebih antara pendapatan dan beban yang mengakibatkan kenaikan ekuitas.

10. Kerugian 
Kerugian merupakan selisih kurang antara pendapatan dan beban yang mengakibatkan penurunan ekuitas.

\section{Asumsi-Asumsi Dasar}

Asumsi digunakan sebagai konsep dasar untuk menyusun laporan keuangan. Asumsi dasar tersebut digunakan untuk menyusun

1. Asumsi Entitas Ekonomi. Merupakan aktivitas ekonomi dapat diidentifikasikan dengan unit pertanggungjwaban tertentu.

2. Asumsi Kelangsungan Hidup (going concern assumption). Artinya perusahaan bisa bertahan untuk melangsungkan operasionalnya.

3. Asumsi unit moneter (monetary unit assumption). arti bahwa uang adalah sebagai alat pengukuran.

4. Asumsi periodisasi (periodicity assumption). Artinya bahwa semua kegiatan ekonomi bisa dipisahkan berdasarkan periode waktu.

\section{Prinsip-Prinsip Dasar Akuntansi}

1. Prinsip Biaya Historis (historical cost principle).. Adalah harga akuisisi yang diakui sebagai nilai aktiva dan kewajiban.

2. Prinsip Pengakuan Pendapatan (revenue recognition principle). Pendapatan diakui pada saat telah dihasilkan atau dapat direalisasi

3. Prinsip Penandingan (matching principle). Adalah membandingkan antara beban dan pendapatan. 
4. Prinsip Perngungkapan Penuh (full disclosure principle). Adalah semua informasi yang disajikan dalam laporan keuangan merupakan semua informasi ekonomi pada perusahaan yang tidak ada yang disembunyikan.

\section{Kendala}

Informasi yang disajikan mengandung informasi yang kualiitatif sehingga ada dua kendala yaitu :

1. Hubungan Biaya Manfaat (cost-benefit relationship). Artinya bahwa biaya yang dikeluarkan harus lebih rendah dari manfaat yang didapatkan

2. Materialitas (materiality). Artinya akan dikatakan material jika besar kecilnya suatu nilai tersebut bisa mempengaruhi keputusan pengguna laporan keuangan.

\section{E. Kesimpulan}

Laporan Keuangan berisi informasi kuantitatif, yang berisikan informasi keuangan agar informasi tersebut bermanfaat bagi pengguna informasi tersebut maka harus memenuhi karakteristik kualitatif. Ada Empat karakteristik kualitatif yaitu: Dapat dipahami, Relevan , Keandalan, Daya uji (verifiability), Ketepatan penyajian (representational faithfullness) Netralitas (neutrality). Terdapat kendala pada terhadap pelaporan informasi akuntansi yaitu Hubungan manfaat dan biaya dan materialitas. . 
Unsur-unsur dasar merupakan aspek yang penting. Unsur-unsur tersebut adalah Aktiva, Kewajiban, Ekuitas, Investasi oleh pemilik, Distribusi kepada pemilik/ Dividen, Laba/Rugi Komprehensif, Pendapatan, Beban, Keuntungan , Kerugian. Asumsi digunakan sebagai konsep dasar untuk menyusun laporan keuangan. Yaitu Aumsi Entitas Ekonomi, Asumsi Kelangsungan Hidup (going concern assumption, Asumsi unit moneter (monetary unit assumption). Asumsi periodisasi (periodicity assumption). Artinya bahwa semua kegiatan ekonomi bisa dipisahkan berdasarkan periode waktu.

Prinsip-Prinsip Dasar Akuntansi yaitu Prinsip Biaya Historis (historical cost principle), Prinsip Pengakuan Pendapatan (revenue recognition principle), Prinsip Penandingan (matching principle). Adalah membandingkan antara beban dan pendapatan., Prinsip Perngungkapan Penuh (full disclosure principle). .

SOAL

1. Sebutkan dan jelaskan asumsi dasar akuntansi!

2. Jelaskan perbedaan konsistensi dan komparabilitas

3. Jelaskan perbedaan Kerugian dan beban

4. Jelaskan perbedaan keuntungan dan laba

5. Jelaskan mengapa dalam akuntansi keuangan kerangka kerja konseptual merupakan hal yang penting. 


\section{Daftar Pustaka}

Keiso, Donald E. Weygandt, Jerry J. Warfield, Terry D. 2007. Akuntansi Intermediate. Penerbit Erlangga. Jakarta.

Martani, Dwi. Dkk. 2016. Akuntansi Keuangan Menengah. Salemba Empat. Jakarta 
Niswonger, C. Rollin. Warren, Carls S. Reeve, James M. 1999.

Prinsip-Prinsip Akuntansi Edisi 19. Penerbit Erlangga. Jakarta

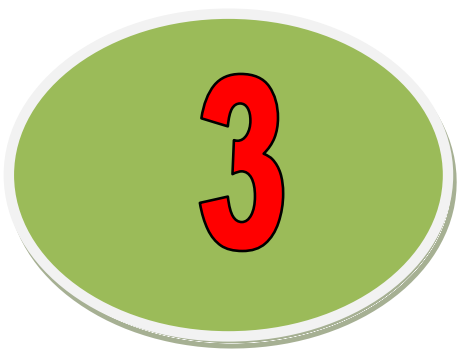




\section{Sistem Infiopmasi}

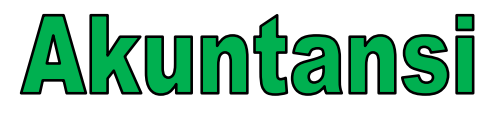

TUJUAN PEMBELAJARAN

Setelah mempelajari bab ini, Anda diharapkan mampu:

1. Memahami dasar akuntansi

2. Memahami mengenai aturan berpasangan

3. Memahami siklus akuntansi

4. Membuat transaksi pada jurnal, buku besar dan neraca saldo

5. Memahami ayat jurnal penyesuaian

\section{BAB III}

SISTEM INFORMASI AKUNTANSI

A. Pendahuluan 
Sistem informasi dibutuhkan oleh perusahaan jika informasi yang dsampaikan mempunyai keandalan, jika informasi yang disampaikan tidak mempunyai nilai akurat atau keandalan maka informasi tersebut tidak akan membantu perusahaan untuk mencapai kinerja yang lebih baik.

\section{B. Debet dan Kredit}

Debet dan Kredit mempunyai arti kiri dan kanan yang biasanya mempunyai singkatan $\mathrm{Dr}$ (Debit) dan $\mathrm{Kr}$ (kredit). Pencatatan debet pada sisi kiri dan kredit pada sisi kanan.

Pencatatan debet dan kredit dalam akuntansi sebagai berikut:

\begin{tabular}{|l|l|l|}
\hline Jenis Akun & Debet & Kredit \\
\hline Aset & Peningkatan (+) & Penurunan (-) \\
\hline Liabilitas & Penurunan (-) & Peningkatan (-) \\
\hline Ekuitas & Penurunan (-) & Peningkatan (+) \\
\hline Pendapatan & Penurunan (-) & Peningkatan (+) \\
\hline Beban & Peningkatan (+) & Penurunan (-) \\
\hline
\end{tabular}

\section{Persamaan Dasar Akuntansi}

Harta perusahaan merupakan kekayaan yang dimiliki oleh perusahaan. Dalam akuntansi, harta disebut aktiva. Pada akuntansi yang disebut aktiva bukan uang tunai saja melainkan semua hak yang bisa dinilai dengan uang, seperti peralatan, 
persediaan dan piutang. Aktiva perusahaan bisa berasal dari investasi ataupun dari pinjaman. Modal pemilik atau disingkat modal merupakan investasi pemilik. Kewajiban (hutang ) merupakan pinjaman dari pihak ketiga yang harus terselesaikan sesuai dengan waktu yang telah disepakati.

Misalnya Bapak Athar mendirikan sebuah perusahaan dengan menginvestasikan uang tunai sejumlah Rp. 100.000.000 ke dalam perusahaan yang didirikan, maka aktiva perusahaan itu pada tanggal pendirian hanya terdiri uang tunai sebesar Rp. 100.000.000. Besar modal perusahaan tersebut sebesar Rp. 100.000.000 jika dinyatakan dengan sebuah persamaan maka susunannya sebagai berikut:

\section{Aktiva $=$ Modal}

Ket : Pendapatan dan beban termasuk dalam ekuitas

Jika aktiva yang berupa uang tunai sejumlah Rp. 100.000.000 itu berasal dari dua sumber misalnya:

1) Pinjaman dari bank sebesar Rp. 25.000 .000

2) Investasi dari pemilik Rp. 75.000 .000

Maka dalam hal ini susunan persamaan itu adalah :

\section{Aktiva $=$ Kewajiban + Modal}

Istilah dalam persamaan dasar akuntansi yang dipakai utuk kewajiban dan modal disebut sebagai pasiva, jadi: 


\section{Atau}

Kewajiban memiliki beberapa jenis, misalnya utang wesel, utang usaha dan sebagainya. Utang usaha timbul karena telah membeli barang dagangan atau memperoleh jasa dengan kredit (dengan pembayaran di waktu yang akan datang). Orang atau badan yang berhutang disebut Debitur, orang atau badan yang memberikan hutang disebut kreditur.

\section{Pengaruh Transaksi Keuangan Terhadap Persamaan Dasar Akuntansi}

Pada setiap transaksi keuangan perusahaan menyebabkan adanya akibat berbagai perubahan dalam ketiga unsure persamaan dasar akuntansi. Perubahan itu bisa timbul pada aktiva saja, atau aktiva dan kewajiban, atau aktiva, kewajiban dan modal. Agar lebih jelas perhatikan contoh-contoh dari transaksi dibawah ini:

\section{Transaksi 1}

Pada tanggal 1 September 2020, Azky memulai perusahaannya dengan menyetor uang tunai pribadinya sebanyak Rp. 180.000 .000 ke salam kas perusahaan. Dampak dari transaksi tersebut maka :

$\checkmark$ Timbulnya aktiva uang kas sebanyak Rp. 180.000.000 dalam perusahaan

$\checkmark \quad$ Uang Rp. 180.000 .000 itu berasal dari uang pemilik, maka ia mempunyai investasi sebanyak $\mathrm{Rp}$. 180.000.000 sebagai modal perusahaan. 
Jadi setelah transaksi tersebut diatas maka persamaan dasar akuntansi perusahaan Azky adalah sebagai berikut : (dalam ribuan)

\begin{tabular}{|llc|}
\hline AKTIVA & $=$ & MODAL \\
\hline Kas & $=$ & Modal Azky \\
\hline RP. 180.000 & $=$ & Rp.180.000 \\
\hline
\end{tabular}

\section{Transaksi 2}

Pada Tanggal 23 September 2020 Perusahaan Azky tersebut membeli dengan tunai sebidang tanah dengan harga Rp. 100.000.000, Akibat transaksi tersebut adalah:

$\checkmark \quad$ Aktiva uang kas berkurang sebesar Rp. 100.000.000

$\checkmark$ Aktiva baru yaitu sebidang tanah sebesar 100.000.000

Unsur-unsur dalam persamaan dasar akuntansi perusahaan Azky sebelum adanya transaksi-transaksi tanggal 1 dan 23 September 2020 maka saldo setelah tanggal 23 September sebagai berikut:

\begin{tabular}{|llc|}
\hline AKTIVA & $=$ & MODAL \\
\hline Kas + Tanah & $=$ & Modal Azky \\
\hline RP. 180.000 & & Rp. 180.000 \\
\hline (Rp. 100.000) + Rp. 100.000 & $=$ & Rp. 180.000 \\
\hline Rp. $80.000+$ Rp. 100.000 & $=$ & Rp. 180.000 \\
\hline
\end{tabular}




\section{Laporan Keuangan}

Berdasarkan PSAK no 1 ada lima jenis laporan keuangan yaitu:

1. Laporan laba rugi komprehensif

2. Laporan posisi keuangan

3. Laporan perubahan ekuitas

4. Laporan arus kas

5. Catatan atas Laporan Keuangan

Laporan keuangan merupakan informasi yang berguna bagi pemakainya, seperti pemilik, manajemen, kreditur, investor untuk pengambilan keputusan seperti:

1. Menentukan untuk memberi pinjaman atau tidak kepada perusahaan

2. Menentukan perusahaan akan berinvestasi atau tidak

\section{SIKLUS AKUNTANSI}

Siklus Akuntansi adalah proses semua yang dilakukan perusahaan untuk mengolah data keuangan untuk menjadi informasi yang berguna untuk mengambil keputusan. Berikut ini merupakan siklus akuntansi 


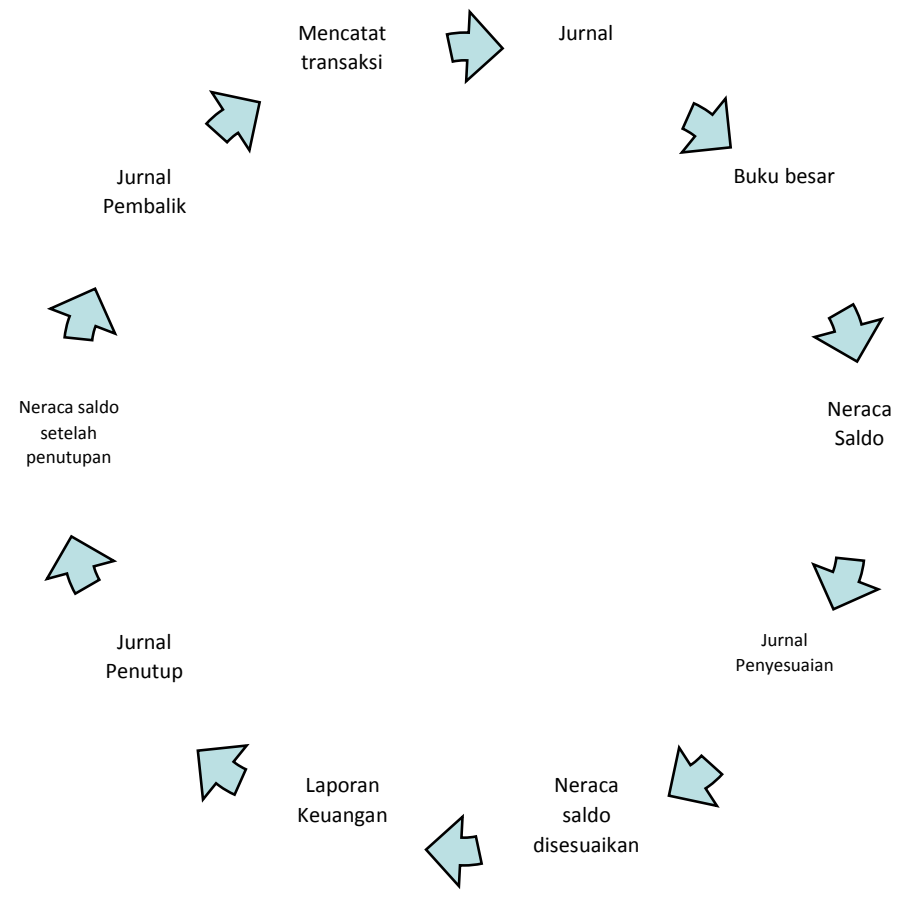

Gambar

Siklus Akuntansi

\section{PENCATATAN TRANSAKSI}

Transaksi adalah suatu kejadian atau peristiwa yang mempunyai dampak terhadap keuangan. Seperti contoh transaksi pada PT. Shah dibawah ini:

1. Bapak Shah menyetor modal sebesar Rp. 50.000 .000 kepada PT. Shah 
2. Membayar gaji pegawai sebesar Rp. 10.000 .000

3. Membeli peralatan kantor sebesar secara kredit Rp. 1.000 .000

4. Menerima pembayaran piutang sebesar Rp. 2.500 .000

Transaksi yang tidak mempunyai dampak terhadap keuangan yaitu:

1. Pengangkatan Bapak Shah sebagai manajer operasional

2. Menerima surat penawaran produk

3. Bapak Athar menyampaikan perhitungan gaji yang baru

\section{JURNAL}

Pencatatan transaksi setiap ada peristiwa dilakukan melalui jurnal umum, pencatatan dilakukan secara urut berdasarkan tanggal peristiwa. Bentuk Jurnal umum sebagai berikut;

Menggunakan ilustrasi PT. Shah di atas, maka jurnal yang dibuat selama bulan September 2020 adalah sebagai berikut:

\begin{tabular}{|l|l|l|l|l|}
\hline Tanggal & Akun & Ref & Debit & Kredit \\
\hline 1 Sept & Kas & & Rp. 50.000.000 & \\
\hline & Modal & & & Rp. 50.000.000 \\
\hline 4 Sept & Beban Gaji & & Rp. 10.000.000 & \\
\hline & Kas & & & Rp. 10.000 .000 \\
\hline
\end{tabular}




\begin{tabular}{|l|l|l|l|l|}
\hline 5 Sept & $\begin{array}{l}\text { Peralatan } \\
\text { kantor }\end{array}$ & & Rp. 1.000.000 & \\
\hline & Utang & & & Rp. 1.000.000 \\
\hline 6 Sept & Kas & & Rp. 2.500.000 & \\
\hline & Piutang & & & Rp. 2.500.000 \\
\hline
\end{tabular}

\section{Pemindahbukuan (Posting)}

Pemindahbukuan merupakan proses untuk klasifikasi untuk dimasukan ke dalam buku besar. Tahapan untuk melakukan pemindahbukuan adalah sebagai berikut:

1) Menganalisis nama-nama akun dan dipindahkan pada kolom debet atau kredit pada akun yang dibuka besar.

2) Untuk kode akun yang dituliskan pada kolom refrensi di jurnal di masukan pada kolom refrensi yang ada di buku besar.

3) Saldo akhir setiap akun dalam buku besar ditentukan

Pemindahbukuan akan dilaksanakan pada tiap transaksi yang dijurnal, berikut ini merupakan contoh buku besar PT. Shah :

Kas

Modal

$1 / 9 \quad 50.000 .000$

10.000 .000 


\section{1/9 50.000 .000 \\ 6/9 2. 500.000 \\ 1.000 .000}

Beban Gaji

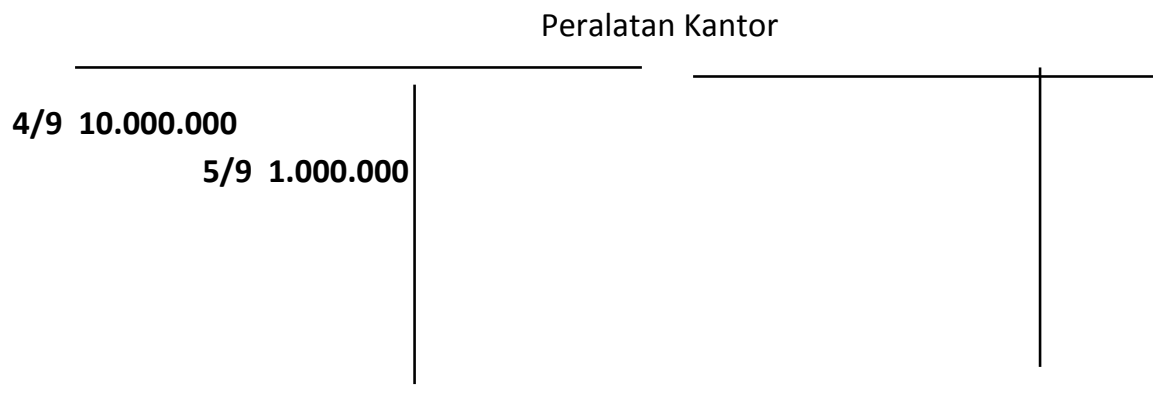

Hutang

Piutang

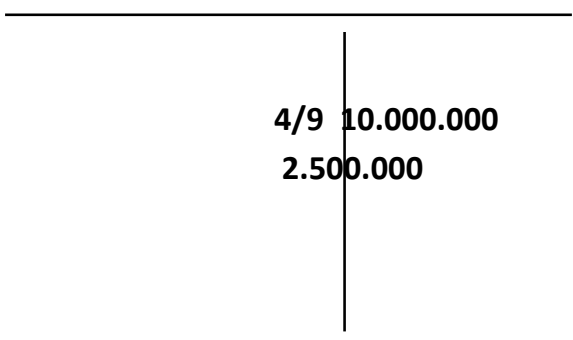

\section{Kesimpulan}

Debet dan Kredit mempunyai arti kiri dan kanan yang biasanya mempunyai singkatan $\mathrm{Dr}$ (Debit) dan Kr (kredit). Pencatatan debet 
pada sisi kiri dan kredit pada sisi kanan. Pencatatan transaksi setiap ada peristiwa dilakukan melalui jurnal umum, pencatatan dilakukan secara urut berdasarkan tanggal peristiwa. Pemindahbukuan merupakan proses untuk klasifikasi untuk dimasukan ke dalam buku besar. Tahapan untuk melakukan pemindahbukuan adalah sebagai berikut:Menganalisis nama-nama akun dan dipindahkan pada kolom debet atau kredit pada akun yang dibuka besar. Untuk kode akun yang dituliskan pada kolom refrensi di jurnal di masukan pada kolom refrensi yang ada di buku besar. Saldo akhir setiap akun dalam buku besar ditentukan. Berdasarkan PSAK no 1 ada lima jenis laporan keuangan yaitu:Laporan laba rugi komprehensif, Laporan posisi keuangan, Laporan perubahan ekuitas, Laporan arus kas dan Catatan atas Laporan Keuangan. Laporan keuangan merupakan informasi yang berguna bagi pemakainya, seperti pemilik, manajemen, kreditur, investor untuk pengambilan keputusan seperti: Menentukan untuk memberi pinjaman atau tidak kepada perusahaan, Menentukan perusahaan akan berinvestasi atau tidak.

Soal

1. Dari transaksi dibawah ini buatlah persamaan dasar akuntansi

\begin{tabular}{|l|l|}
\hline Tanggal & Keterangan \\
\hline 1 Jan & $\begin{array}{l}\text { PT. ABC memperoleh uang tunai sebesar Rp. } \\
50.000 .000 \text { dari pemilik untuk seteron modal }\end{array}$ \\
\hline 3 Jan & $\begin{array}{l}\text { PT. ABC membeli tunai kendaraan RP. } \\
\text { 10.000.000 secara tunai }\end{array}$ \\
\hline 4 Jan & $\begin{array}{l}\text { PT. ABC membeli perlengkapan secara kredit } \\
\text { sebesar Rp. 1.000.000 kepada UD. Makmur }\end{array}$ \\
\hline 5 Jan & $\begin{array}{l}\text { PT. ABC memperoleh penghasilan RP. } \\
5.000 .000 \text { dari penyewaan kendaraan ke } \\
\text { pelanggan }\end{array}$ \\
\hline
\end{tabular}




\begin{tabular}{|l|l|}
\hline 6 Jan & $\begin{array}{l}\text { PT. ABC melunasi semua hutang kepada UD. } \\
\text { Makmur (lihat transaksi tanggal 4) }\end{array}$ \\
\hline 8 Jan & $\begin{array}{l}\text { PT. ABC membayar tagihan listrik sebesar Rp. } \\
500.000\end{array}$ \\
\hline 10 Jan & $\begin{array}{l}\text { PT. ABC membeli mesin secara runai sebesar } \\
\text { Rp. } 4.000 .000\end{array}$ \\
\hline
\end{tabular}

2. Dari data dibawah ini buatlah jurnal penutup dan jelaskan fungsi jurnal penutup!

\section{Perusahaan SHAH, Sidoarjo \\ LAPORAN LABA/ RUGI}

31 DESEMBER 2016

\begin{tabular}{|c|c|c|c|}
\hline Pendapatan usaha & & & \\
\hline Pendapatan jasa & & 27.000 .000 & \\
\hline Beban perjalanan dinas & 10.000 .000 & & \\
\hline Beban iklan & 900.000 & & \\
\hline Beban telepon & 600.000 & & \\
\hline Beban listrik dan air & 400.000 & & \\
\hline Beban Perlengkapan Kantor & 600.000 & & \\
\hline Beban sewa & 450.000 & & \\
\hline $\begin{array}{l}\text { Beban penyusutan peralatan } \\
\text { kantor }\end{array}$ & 700.000 & & \\
\hline Jumlah beban & & & $(13.650 .000)$ \\
\hline Laba usaha & & & 13.350 .000 \\
\hline
\end{tabular}

\section{LAPORAN PERUBAHAN MODAL}

\begin{tabular}{|l|l|}
\hline $\begin{array}{l}\text { Modal tuan shah 1 desember } \\
2016\end{array}$ & 150.000 .000 \\
\hline Laba bersih 2016 & $\underline{13.350 .000}$ \\
\hline & 163.350 .000 \\
\hline Pengambilan prive & $(5.000 .000)$ \\
\hline Modal Tuan shah & 158.350 .000 \\
\hline
\end{tabular}


3. Dari data dibawah ini buatlah jurnal koreksi dengan metode dua langkah dan satu langkah!

I. Pada tanggal 4 mei CV. Cahaya membeli secara tunai perlengkapan kantor sebesar 500.000 tetapi dicatat oleh bagian akuntansi sebagai peralatan

II. Pada tanggal 6 Mei CV. Cahaya memperoleh penghasilan usaha Rp. 24.000 .000 secara tunai tetapi oleh bagian akuntansi dicatat sebesar 42.000 .000

4. Dari data dibawah Buatlah jurnal umum dan jurnal penyesuaian ( tutup buku tanggal 31 Desember 2018) dari transaksi dibawah ini!
A. Pada tanggal 1 April 2018 PT YC memperoleh pendapatan sewa sebesar Rp. 1.200 .000 ( dengan pendekatan neraca)
B. Pada tanggal 1 Maret 2018 PT YC membayar biaya iklan untuk 1 tahun sebesar RP. 12.000.000 (dengan pendekatan laba rugi)
C. PT YC belum membayar gaji pegawai sebesar RP. 4.000.000 yang seharusnya sudah dibayarkan

5. Berikut ini informasi saldo akun-akun di PT. Jaya Abadi per 31 Desember 2018.

\begin{tabular}{|l|l|}
\hline Kas & $1,700,000$ \\
\hline Piutang usaha & $1,250,000$ \\
\hline & \\
Perlengkapan kantor & 50,000 \\
\hline Beban sewa dibayar dimuka & \\
\hline
\end{tabular}




\begin{tabular}{|l|l|}
\hline & 200,000 \\
\hline Kendaraan & $5,000,000$ \\
\hline Peralatan kantor & $1,200,000$ \\
\hline Utang usaha & $2,500,000$ \\
\hline Modal & $5,000,000$ \\
\hline Pendapatan & $2,440,000$ \\
\hline Beban iklan & 40,000 \\
\hline Beban gaji & \\
\hline
\end{tabular}

Informasi untuk pencatatan penyesuaian per 31 Desember 2018:

a. Hasil perhitungan fisik diketahui bahwa perlengkapan kantor yang masih di gudang bernilai Rp. 20.000

b. Besarnya beban penyusutan peralatan kantor untuk periode 2018 ditetapkan sebesar Rp. 120.000

c. Sewa kantor yang pembayarannya dilakukan dimuka (lihat akun beban sewa dibayar dimuka pada daftar saldo diatas) merupakan transaksi tanggal 2 Juli 2018 untuk penyewaan selama 1 tahun.

d. Besarnya beban penyusutan kendaraan sebesar RP. 500.000

e. Perusahaan harus mengakui beban iklan Rp. 100.000 yang belum dibayarkan tetapi iklan sudah ditayangkan di mperiode ini

Dari data diatas buatlah:

1. Jurnal penyesuaian

2. Neraca saldo setelah penyesuain dan laporan laba rugi 


\begin{tabular}{|c|c|c|}
\hline \multirow{2}{*}{ keterangan } & \multicolumn{2}{|c|}{ Daftarsaldo } \\
\hline & debet & Kredit \\
\hline Kas & Rp160,000 & \\
\hline Piutang usaha & Rp165,000 & \\
\hline Persediaan barang jadi & Rp175,000 & \\
\hline Persediaan BDP & Rp50,000 & \\
\hline Persediaan Bahan Baku & Rp75,000 & \\
\hline Perlengkapan kantor & Rp55,000 & \\
\hline Aset tetap & Rp350,000 & \\
\hline Akum penyusutann AT & & $\mathrm{Rp} 35,000$ \\
\hline Utang usaha & & Rp175,000 \\
\hline Utang Bank & & $\mathrm{Rp} 300,000$ \\
\hline Modal saham & & Rp375,000 \\
\hline Laba ditahan & & Rp60,000 \\
\hline Deviden & Rp78,000 & \\
\hline Pejualan & & Rp500,000 \\
\hline Pembelian bahan baku & Rp135,000 & \\
\hline Biaya TKL & Rp55,000 & \\
\hline BiayaBahan penolong & Rp20,000 & \\
\hline Biaya TKP & Rp30,000 & \\
\hline Biaya pabrikasi lain & Rp35,000 & \\
\hline Biaya pemasaran & Rp32,000 & \\
\hline Biaya admin dan umum & Rp30,000 & \\
\hline Total & $\mathrm{Rp} 1,445,000$ & Rp1,445,000 \\
\hline
\end{tabular}




\section{KETERANGAN:}

1. Perlengkapan kantor yang tersisa pada bulan mei 2014 sebesar Rp. 20.000 .000

2. Persediaan barang jadi pada akhir bulan mei 2014 sebesar RP. 130.000 .000

3. Persediaan barang dalam proses pada akhir bulan mei 2014 sebesar Rp. 40.000.000

4. Persediaan bahan baku pada akhir bulan mei 2014 sebesar Rp. 25.000.000

5. Biaya penyusutan asset tetap pada bulan mei 2014 sebesarRp. 2.500.000

Dari data diatasbuatlah:

1. Jurnal penyesuaian

2. Neraca lajur

3. Laba rugi

DibawahiniadalahtransaksidariperusahaanJasaReparasim obil "ROSSA"

\begin{tabular}{|l|l|lr|}
\hline $\begin{array}{l}\text { BL } \\
\text { N }\end{array}$ & $\begin{array}{l}\text { T } \\
\text { G } \\
\text { L }\end{array}$ & KETERANGAN \\
\hline M & 1 & $\begin{array}{l}\text { Menerimapendapatansecaratunaidaripelangga } \\
\text { natasjasareparasisebesar RP. 10..000.000 }\end{array}$ \\
\hline & 3 & $\begin{array}{l}\text { Penerimaanpiutangkaryawan } \\
\text { dipotongdarigajikaryawansebesar }\end{array}$ & yang \\
& & R.000.000 \\
\hline & 5 & $\begin{array}{l}\text { Diterimapelunasanpiutangdaripelanggansebes } \\
\text { arRp. 10.000.000 }\end{array}$ \\
\hline & 6 & $\begin{array}{l}\text { Membeliperlengkapankantor } \\
\text { sebesarRp. 1.000.000 }\end{array}$ \\
\hline
\end{tabular}




\begin{tabular}{|c|c|}
\hline 7 & $\begin{array}{l}\text { Membayarhutangkepada distributor olisebesar } \\
\text { RP. 5.000.000 }\end{array}$ \\
\hline 8 & $\begin{array}{lr}\text { dibeliperalatanbengkeldanperlengkapanbengk } \\
\text { elmasing-masingsehargaRp } & 2.000 .000,00 \\
\text { danRp } & 1.750 .000,0 \\
\text { Jumlahtersebutdibayartunai. } & \\
\end{array}$ \\
\hline 9 & $\begin{array}{l}\text { Membeliperlengkapanbengkelsebesar } \\
\text { 1.000.000 dibayartunai }\end{array}$ \\
\hline 10 & Membayargajipegawaisebesar RP. 5.000 .000 \\
\hline 11 & Membayarlistrikdan air sebesarRp. 500.000 \\
\hline 12 & $\begin{array}{l}\text { MembayarsewauntukruanganbengkelRp } \\
\text { 3.000.000,00. }\end{array}$ \\
\hline 14 & DiterimatunaipendapatanservisRp 800.000 \\
\hline 16 & $\begin{array}{l}\text { Diterimauangmukauntukpekerjaan } \\
\text { mobilRp } 4.000 .000\end{array}$ \\
\hline 17 & $\begin{array}{l}\text { Dikirimfakturpenagihanataspekerjaan cat } \\
\text { mobil yang telahselesaidikerjakanRp } \\
1.500 .000,00 \quad \text { kepadausahapengangkutan } \\
\text { REJO }\end{array}$ \\
\hline 18 & $\begin{array}{l}\text { Diterimapendapatanservisatasmobil yang } \\
\text { telahselesaidikerjakansejumlahRp } 500.000,00\end{array}$ \\
\hline 20 & $\begin{array}{l}\text { AngkutanRejomembayartagihansebesarRp. } \\
1.500 .000\end{array}$ \\
\hline 21 & $\begin{array}{l}\text { PelangganservismobilsebesarRp. } 4.000 .000, \\
\text { tetapibarudibayarsetengahnya, } \\
\text { sisanyaakandilunasibulanberikutnya. }\end{array}$ \\
\hline
\end{tabular}

Dari transaksidiatassaudaradimintamembuat:

1. Jurnal

2. Bukubesar

3. Neracasaldo 


\begin{tabular}{|c|c|c|c|c|}
\hline Kas & $\mathrm{Rp}$ & 150,000 & & \\
\hline Piutang usaha & $\mathrm{Rp}$ & 180,000 & & \\
\hline Persediaan barang jadi & $\mathrm{Rp}$ & 170,000 & & \\
\hline Persediaan BDP & $\mathrm{Rp}$ & 50,000 & & \\
\hline Persediaan Bahan Baku & $\mathrm{Rp}$ & 80,000 & & \\
\hline Perlengkapan kantor & $\mathrm{Rp}$ & 60,000 & & \\
\hline Aset tetap & $\mathrm{Rp}$ & 400,000 & & \\
\hline Akum penyusutann AT & & & $\mathrm{Rp}$ & 40,000 \\
\hline Utang usaha & & & $\mathrm{Rp}$ & 100,000 \\
\hline Utang Bank & & & $\mathrm{Rp}$ & 250,000 \\
\hline Modal saham & & & $\mathrm{Rp}$ & 450,000 \\
\hline Laba ditahan & & & $\mathrm{Rp}$ & 80,000 \\
\hline Deviden & $\mathrm{Rp}$ & 60,000 & & \\
\hline Pejualan & & & Rp. & 515.000 \\
\hline Pembelian bahan baku & $\mathrm{Rp}$ & 120,000 & & \\
\hline Biaya TKL & $\mathrm{Rp}$ & 40,000 & & \\
\hline Biaya Bahan penolong & $\mathrm{Rp}$ & 20,000 & & \\
\hline Biaya TKP & $\mathrm{Rp}$ & 30,000 & & \\
\hline Biaya pabrikasi lain & $\mathrm{Rp}$ & 20,000 & & \\
\hline Biaya pemasaran & $\mathrm{Rp}$ & 25,000 & & \\
\hline Biaya admin dan umum & $\mathrm{Rp}$ & 30,000 & & \\
\hline Total & $\mathrm{Rp}$ & $1,435,000$ & $\mathrm{Rp}$ & $1,435,000$ \\
\hline
\end{tabular}

KETERANGAN:

6. Perlengkapan kantor yang tersisa pada bulan mei 2014 sebesar Rp. 10.000

7. Persediaan barang jadi pada akhir bulan mei 2014 sebesar RP. 100.000 
8. Persediaan barang dalam proses pada akhir bulan mei 2014 sebesar Rp. 20.000

9. Persediaan bahan baku pada akhir bulan mei 2014 sebesar Rp. 40.000

10. Biaya penyusutan asset tetap pada bulan mei 2014 sebesar Rp. 20.000

Dari data diatas buatlah:

1. Jurnal penyesuaian

2. Neraca lajur

3. Laporan laba rugi 


\section{Daftar Pustaka}

Keiso, Donald E. Weygandt, Jerry J. Warfield, Terry D. 2007. Akuntansi Intermediate. Penerbit Erlangga. Jakarta.

Martani, Dwi. Dkk. 2016. Akuntansi Keuangan Menengah. Salemba Empat. Jakarta

Niswonger, C. Rollin. Warren, Carls S. Reeve, James M. 1999. Prinsip-Prinsip Akuntansi Edisi 19. Penerbit Erlangga. Jakarta 


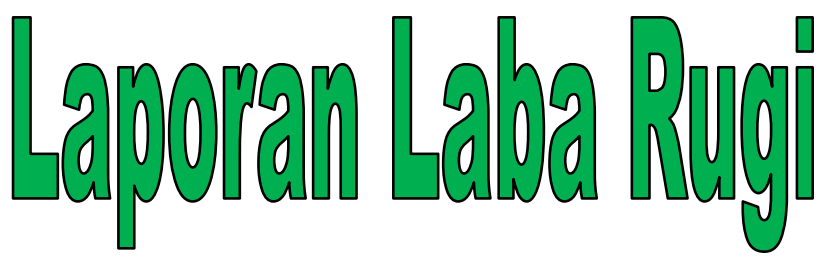

TUJUAN PEMBELAJARAN

Setelah mempelajari bab ini, Anda diharapkan mampu:

1. Memahami fungsi dan Keterbatasan Laba/rugi

2. Memahami kualitas laba

3. Membuat laporan laba ditahan

BAB IV

LAPORAN LABA RUGI DAN INFORMASI YANG BERHUBUNGAN

Pendahuluan 
Salah satu jenis laporan keuangan yang bisa menunjukan kemampuan perusahaan untuk menghasilkan laba yaitu laporan laba rugi komprehensif. Melalui laporan ini kita bisa melihat bagaimana kemampuan perusahaan untuk mendapatkan laba, dan dari laporan laba rugi tersebut kita juga bisa mengetahui kinerja perusahaan.

\section{LAPORAN LABA-RUGI}

Laporan laba-rugi (statement of income) Laporan yang menunjukan kinerja perusahaan pada periode waktu tertentu.

\section{Fungsi laporan laba-Rugi}

Laporan laba-rugi mempunyai beberapa manfaat seperti:

1. Memprediksi arus kas masa depan

2. Memprediksi kinerja perusahaan diperiode berikutnya

3. Mengevaluasi kinerja sebelumnya dan menentukan rencana kedepan

4. Menilai resiko

\section{Keterbatasan Laporan Laba-Rugi}

1. Angka yang ada pada laporan laba rugi tergantung dari metode akuntansi yang digunakan misalnya: metode persediaan Lifo dan fifo akan menghasilkan angka yang berbeda pada laporan laba-rugi 
2. Pos-pos atau angka yang tidak dapat diukur secara akurat tidak dilaporkan dalam laporan laba-rugi

\section{Kualitas Laba}

Pengelolaan laba adalah (earnings management) adalah Pengelolaan laba merupakan tindakan yang dilakukan untuk menghasilkan laporan laba rugi sesuai dengan kehendak manajemen, misalnya dengan cara menaikan laba hal ini akan berdampak pada kualitas laba karena laba yang dihasilkan tidak sesuai dengan kondisi real perusahaan sehingga akan berakibat kualitas laba nya tidak bagus.

\section{Format laporan laba rugi}

\section{Unsur Unsur Laporan Laba-Rugi}

- Pendapatan, Peningkatan aktiva adanya aliran masuk aktiva karena adanya operasional perusahaan.

- Beban, Penurunan aktiva karena adanya operasional perusahaan

- Keuntungan, Kenaikan ekuitas karena adanya operasional perusahaan

- Kerugian, Penurunan ekuitas perusahaan dari operasional perusahaan

\section{Laporan Laba-Rugi Bentuk Langsung}


Laporan Laba-Rugi Bentuk Langsung hanya ada dua pengelompokan:yaitu pendapatan dan beban. Perusahaan menggunakan laporan laba-rugi bentuk langsung dalam pelaporan keuangan karena bentuknya yang sederhana.

\section{Laporan Laba Rugi}

Untuk tahun yang berakhir 31 desember 2020

\section{Pendapatan}

Penjualan bersih

Pendapatan deviden

Pendapatan sewa

Total

pendapatan

\section{Beban}

Harga pokok penjualan

Beban penjualan

Beban adminitrasi

Beban gaji

Beban pajak

Total 
beban

Laba bersih

Laba per saham biasa

Laporan laba rugi bertahap

Untuk laporan laba rugi bentuk bertahap ada beberapa kelompok yang dibedakan yaitu:

1. Adanya Pemisahan aktifitas operasi dan non operasi perusahaan

2. Adanya Klasifikasi beban berdasarkan fungsinya

Laporan laba rugi

Untuk tahun yang berakhir 31 desember 2020

Pendapatan penjualan

Penjualan

$\mathrm{XXX}$

Dikurangi

diskon

penjualan

(xxx) 


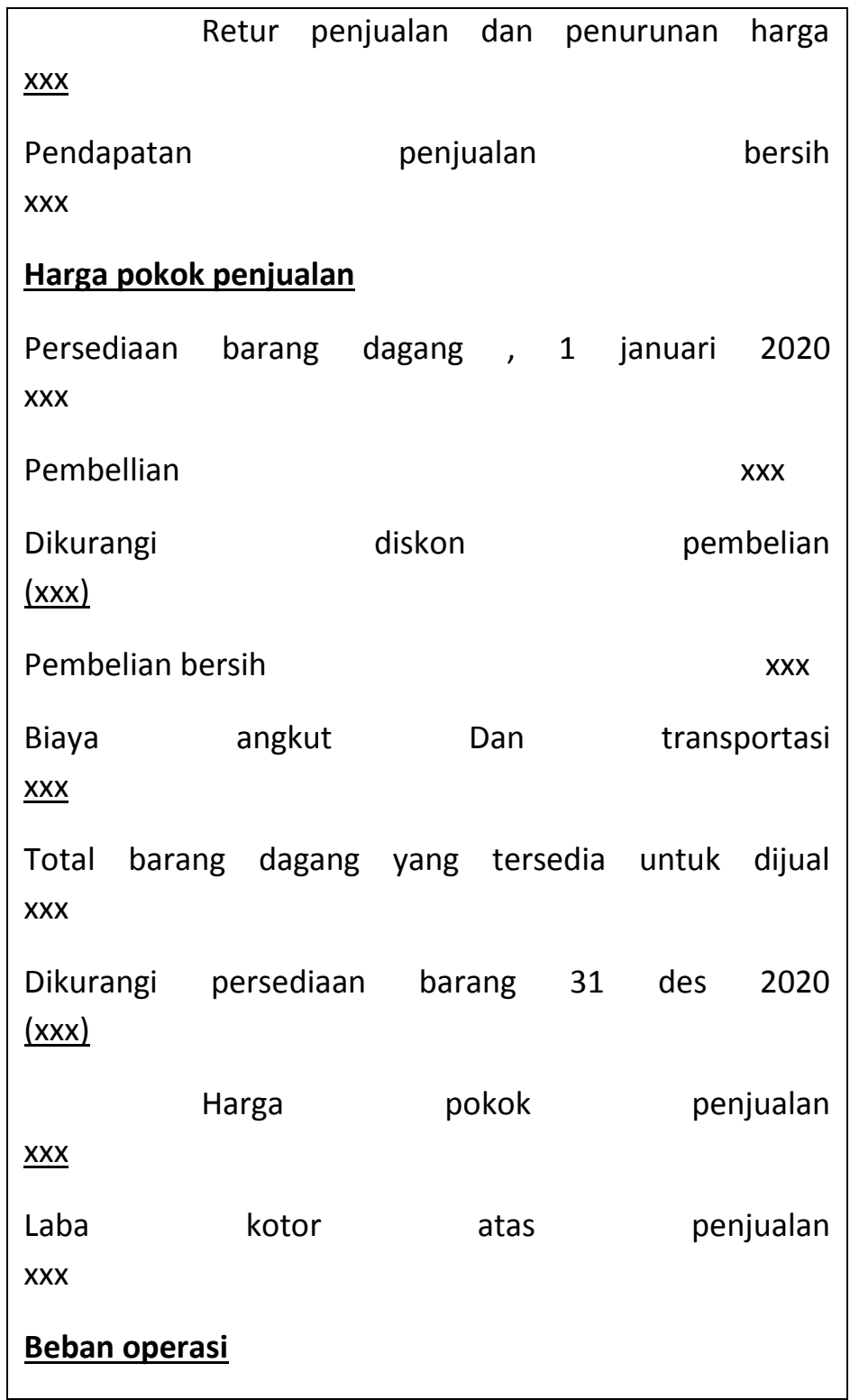




\begin{tabular}{|c|c|c|c|}
\hline \multicolumn{4}{|c|}{ Beban penjualan } \\
\hline & Gaji & komisi & penjualan \\
\hline \multicolumn{4}{|l|}{$x x x$} \\
\hline & Gaji & kantor & penjualan \\
\hline \multicolumn{4}{|l|}{$x x x$} \\
\hline \multicolumn{3}{|c|}{ Penyusutan } & peralatan \\
\hline \multicolumn{4}{|l|}{$x x x$} \\
\hline & Beban & telepon & internet \\
\hline \multicolumn{4}{|l|}{$x x x$} \\
\hline \multicolumn{4}{|c|}{ Beban adminitasi } \\
\hline & Beban & & utilitas \\
\hline \multicolumn{4}{|l|}{$x x x$} \\
\hline & Beban & & asuransi \\
\hline \multicolumn{4}{|l|}{$x x x$} \\
\hline & Penyusutan & & bangunan \\
\hline \multicolumn{4}{|l|}{$x x x$} \\
\hline & Penyusutan & peralatan & kantor \\
\hline \multicolumn{4}{|l|}{$x x x$} \\
\hline & Beban & kantor & rupa-rupa \\
\hline \multicolumn{4}{|l|}{$x x x$} \\
\hline Laba & & dan & operasi \\
\hline$x x x$ & & & \\
\hline
\end{tabular}




\begin{tabular}{|c|c|c|c|}
\hline \multicolumn{4}{|c|}{ Pendapatan dan keuntungan lainnya } \\
\hline \multicolumn{3}{|c|}{ Pendapatan } & deviden \\
\hline \multicolumn{4}{|l|}{$x x x$} \\
\hline \multicolumn{3}{|c|}{ Pendapatan } & sewa \\
\hline \multicolumn{4}{|l|}{$x x x$} \\
\hline \multicolumn{4}{|c|}{ Beban kerugian lainnya } \\
\hline & Bunga & & wesel \\
\hline \multicolumn{4}{|l|}{$x x x$} \\
\hline Laba & sebelum & pajak & penghasilan \\
\hline \multicolumn{4}{|l|}{$x x x$} \\
\hline & Pajak & & penghasilan \\
\hline \multicolumn{4}{|l|}{$x x x$} \\
\hline Laba & & & bersih \\
\hline \multicolumn{4}{|l|}{$x x x$} \\
\hline Laba & per & saham & biasa \\
\hline$x x x$ & & & \\
\hline
\end{tabular}

\section{LAPORAN POS-POS TIDAK BIASA}

Pos-pos tidak biasa terbagi dalam enam kategori:

1. Operasi yang dihentikan yaitu perusahaan menghentikan operasi perusahaan, misalnya perusahaan menghilangkan 
salah satu operasi perusahaan misalnya perusahaan tidak lagi memproduksi produk A.

2. Pos-pos luar biasa yaitu aktivitas perusahaan yang bukan berasal sdari aktivitas utama perusahaan dan dari aktivitas tersebut merupakan pos-pos yang jarang muncul.

3. Keuntungan dan kerugian yang tidak biasa maksudnya adalah keuntungan dan kerugian yang tidak berasal dari aktivitas utama perusahaan

4. Perubahan perinsip akuntansi merupakan adanya perubahan prinsip akuntansi dari jenis satu ke jenis lainya, misalnya dari metode penyusutan garis lurus ke metode penyusutan jam jasa

5. Perubahan estimasi merupakan adanya penyesuaian atau koreksi estimasi misalnya tahun sebelumnya perusahaan mengestimasi nilai sisa dari peralatan A adalah Rp. 10.000.000 ternyata pada tahun berikutnya estimasi nilai sisa berubah menjadi Rp, 15.000 .000

\section{Laba per saham}

Perhitungan laba persaham adalah laba bersih setelah dikurangi dengan dividen saham preferen di bagi dengan rata-rata tertimbang saham biasa yang beredar.

Laba Bersih - Dividen SahamPreferen

$$
\text { = laba per saham }
$$

Rata-rata tertimbang Saham Biasa yang beredar 


\section{Laporan laba Ditahan}

Laba bersih akan mengakibatkan kenaikan pada laba ditahan dan rugi bersih akan mengakibatkan penurunkan laba ditahan. Untuk pembagian dividen tunai maupun dividen saham akan menurunkan laba ditahan.

Informasi yang berhubungan dengan laba ditahan bisa ditujukan dengan beberapa cara;

\section{Laporan Laba ditahan}

Untuk Tahun yang Berakhir 31 Desember 2020

Laba ditahan,1 januari,seperti yang dilaporkan Rp. 2.000 .000

Ditambah :laba bersih Rp.

$\underline{500.000}$

2.500 .000

Dikurangi:Dividen tunai Rp. 400.000

Dividen saham Rp. $\underline{100.000}$ 
Rp. 2.000 .000

\section{Laba komprehensif}

Laba komprehensif merupakan semua pendapatan, beban, keuntungan dan kerugian baik yang berasal dari aktivitas utama perusahaan maupun yang bukan berasal dari aktivitas utama perusahaan.

\section{Laporan Ekuitas pemegang Saham}

Laporan ini merupakan laporan yang mengenai perubahan ekuitas pemegang saham. Misalnya adalah PT. A memiliki akun ekuitas pemegang saham berikut pada awal tahun 2020: saham biasa, Rp. 500.000, Laba Ditahan, Rp.100.000, dan akumulasi laba Komprehensif lainnya Rp.100.000 tidak ada perubahan yang terjadi dalam akun saham biasa selama tahun berjalan.

\section{Kesimpulan}

Pengelolaan laba adalah (earnings management) adalah Pengelolaan laba merupakan tindakan yang dilakukan untuk 
menghasilkan laporan laba rugi sesuai dengan kehendak manajemen, misalnya dengan cara menaikan laba hal ini akan berdampak pada kualitas laba karena laba yang dihasilkan tidak sesuai dengan kondisi real perusahaan sehingga akan berakibat kualitas laba nya tidak bagus. Pendapatan, Peningkatan aktiva adanya aliran masuk aktiva karena adanya operasional perusahaan. Beban, Penurunan aktiva karena adanya operasional perusahaan. Keuntungan , Kenaikan ekuitas karena adanya operasional perusahaan .Kerugian, Penurunan ekuitas perusahaan dari operasional perusahaan. Laporan Laba-Rugi Bentuk Langsung hanya ada dua pengelompokan:yaitu pendapatan dan beban. Perusahaan menggunakan laporan laba-rugi bentuk langsung dalam pelaporan keuangan karena bentuknya yang sederhana.

Soal

1. Jelaskan apa perbedaan keuntungan dan kerugian serta dampaknya terhadap aktiva?

2. Jelaskan apa saja yang bisa menyebabkan saldo laba mengalami peningkatan?

3. Jelaskan fungsi laporan laba rugi? 
5. Dari transaksi dibawah ini buatlah persamaan dasar akuntansi

\begin{tabular}{|l|l|}
\hline Tanggal & Keterangan \\
\hline 1 Jan & $\begin{array}{l}\text { PT. ABC memperoleh uang tunai } \\
\text { sebesar Rp. 60.000.000 dari pemilik } \\
\text { untuk seteron modal }\end{array}$ \\
\hline 3 Jan & $\begin{array}{l}\text { PT. ABC membeli tunai kendaraan RP. } \\
\text { 20.000.000 secara tunai }\end{array}$ \\
\hline 4 Jan & $\begin{array}{l}\text { PT. ABC membeli perlengkapan } \\
\text { secara kredit sebesar Rp. 1.000.000 } \\
\text { kepada UD. Makmur }\end{array}$ \\
\hline 6 Jan & $\begin{array}{l}\text { PT. ABC memperoleh penghasilan RP. } \\
\text { 5.000.000 dari penyewaan kendaraan } \\
\text { ke pelanggan }\end{array}$ \\
\hline $\begin{array}{l}\text { PT. ABC melunasi semua hutang } \\
\text { kepada UD. Makmur (lihat transaksi } \\
\text { tanggal 4) }\end{array}$ \\
\hline 10 Jan & $\begin{array}{l}\text { PT. ABC membayar tagihan listrik } \\
\text { sebesar Rp. } 500.000\end{array}$ \\
\hline $\begin{array}{l}\text { PT. ABC membeli mesin secara runai } \\
\text { sebesar Rp. 4.000.000 }\end{array}$ \\
\hline
\end{tabular}

6. Dari data dibawah ini buatlah jurnal penutup dan jelaskan fungsi jurnal penutup!

\section{Perusahaan SHAH, Sidoarjo \\ LAPORAN LABA/ RUGI}


31 DESEMBER 2016

\begin{tabular}{|l|l|l|}
\hline Pendapatan usaha & & \\
\hline Pendapatan jasa & & 27.000 .000 \\
\hline Beban perjalanan dinas & 10.000 .000 & \\
\hline Beban iklan & 900.000 & \\
\hline Beban telepon & 600.000 & \\
\hline Beban listrik dan air & 400.000 & \\
\hline Beban Perlengkapan Kantor & 600.000 & \\
\hline Beban sewa & 450.000 & \\
\hline Beban penyusutan peralatan kantor & 700.000 & \\
\hline Jumlah beban & & $(13.650 .000)$ \\
\hline Laba usaha & & 13.350 .000 \\
\hline
\end{tabular}

\section{LAPORAN PERUBAHAN MODAL}

\begin{tabular}{|l|l|}
\hline $\begin{array}{l}\text { Modal tuan shah 1 } \\
\text { desember } 2016\end{array}$ & 150.000 .000 \\
\hline Laba bersih 2016 & $\underline{13.350 .000}$ \\
\hline & 163.350 .000 \\
\hline Pengambilan prive & $(5.000 .000)$ \\
\hline Modal Tuan shah & 158.350 .000 \\
\hline
\end{tabular}

7. Dari data dibawah ini buatlah jurnal koreksi dengan metode dua langkah dan satu langkah!

III. Pada tanggal 4 mei CV. Cahaya membeli secara tunai perlengkapan kantor sebesar 600.000 tetapi dicatat oleh bagian akuntansi sebagai peralatan 
IV. Pada tanggal 6 Mei CV. Cahaya memperoleh penghasilan usaha Rp. 24.000 .000 secara tunai tetapi oleh bagian akuntansi dicatat sebesar 12.000 .000

8. Dari data dibawah Buatlah jurnal umum dan jurnal penyesuaian ( tutup buku tanggal 31 Desember 2018) dari transaksi dibawah ini!

D. Pada tanggal 1 April 2018 PT YC memperoleh pendapatan sewa sebesar Rp. 1.200.000 ( dengan pendekatan neraca)

E. Pada tanggal 1 Maret 2018 PT YC membayar biaya iklan untuk 1 tahun sebesar RP. $\quad 12.000 .000$ (dengan pendekatan laba rugi)

F. PT YC belum membayar gaji pegawai sebesar RP. 4.000.000 yang seharusnya sudah dibayarkan

5. Berikut ini informasi saldo akun-akun di PT. Jaya Abadi per 31 Desember 2018.

\begin{tabular}{|l|l|}
\hline Kas & $1,700,000$ \\
\hline Piutang usaha & $1,250,000$ \\
\hline Perlengkapan kantor & \\
\hline
\end{tabular}




\begin{tabular}{|l|l|}
\hline & 50,000 \\
\hline Beban sewa dibayar dimuka & 200,000 \\
\hline Peralatan kantor & $5,000,000$ \\
\hline Utang usaha & $1,200,000$ \\
\hline Modal & $2,500,000$ \\
\hline Pendapatan & $5,000,000$ \\
\hline Beban iklan & $2,440,000$ \\
\hline Beban gaji & 40,000 \\
\hline
\end{tabular}

Informasi untuk pencatatan penyesuaian per 31 Desember 2018:

f. Hasil perhitungan fisik diketahui bahwa perlengkapan kantor yang masih di gudang bernilai Rp. 10.000

g. Besarnya beban penyusutan peralatan kantor untuk periode 2018 ditetapkan sebesar Rp. 100.000

h. Sewa kantor yang pembayarannya dilakukan dimuka (lihat akun beban sewa dibayar dimuka 
pada daftar saldo diatas) merupakan transaksi tanggal 2 Juli 2018 untuk penyewaan selama 1 tahun.

i. Besarnya beban penyusutan kendaraan sebesar RP. 500.000

j. Perusahaan harus mengakui beban iklan Rp. 100.000 yang belum dibayarkan tetapi iklan sudah ditayangkan di mperiode ini

Dari data diatas buatlah:

1. Jurnal penyesuaian

2. Neraca saldo setelah penyesuain dan laporan laba rugi

9. Dari transaksi dibawah ini buatlah persamaan dasar akuntansi

\begin{tabular}{|l|l|}
\hline Tanggal & Keterangan \\
\hline 1 Jan & $\begin{array}{l}\text { PT. ABC memperoleh uang tunai } \\
\text { sebesar Rp. 60.000.000 dari pemilik } \\
\text { untuk seteron modal }\end{array}$ \\
\hline 3 Jan & $\begin{array}{l}\text { PT. ABC membeli tunai kendaraan } \\
\text { RP. 20.000.000 secara tunai }\end{array}$ \\
\hline 4 Jan & $\begin{array}{l}\text { PT. ABC membeli perlengkapan } \\
\text { secara kredit sebesar Rp. 1.000.000 } \\
\text { kepada UD. Makmur }\end{array}$ \\
\hline 5 Jan & $\begin{array}{l}\text { PT. ABC memperoleh penghasilan } \\
\text { RP. 5.000.000 dari penyewaan } \\
\text { kendaraan ke pelanggan }\end{array}$ \\
\hline 6 Jan & $\begin{array}{l}\text { PT. ABC melunasi semua hutang } \\
\text { kepada UD. Makmur (lihat transaksi }\end{array}$ \\
\hline
\end{tabular}




\begin{tabular}{|l|l|}
\hline & tanggal 4) \\
\hline 8 Jan & $\begin{array}{l}\text { PT. ABC membayar tagihan listrik } \\
\text { sebesar Rp. 500.000 }\end{array}$ \\
\hline 10 Jan & $\begin{array}{l}\text { PT. ABC membeli mesin secara runai } \\
\text { sebesar Rp. 4.000.000 }\end{array}$ \\
\hline
\end{tabular}

10. Dari data dibawah ini buatlah jurnal penutup dan jelaskan fungsi jurnal penutup!

\section{Perusahaan SHAH, Sidoarjo \\ LAPORAN LABA/ RUGI \\ 31 DESEMBER 2016}

\begin{tabular}{|l|l|l|}
\hline Pendapatan usaha & & \\
\hline Pendapatan jasa & & 2 \\
\hline Beban perjalanan dinas & 10.000 .000 & \\
\hline Beban iklan & 900.000 & \\
\hline Beban telepon & 600.000 & \\
\hline Beban listrik dan air & 400.000 & \\
\hline Beban Perlengkapan Kantor & 600.000 & \\
\hline Beban sewa & 450.000 & \\
\hline Beban penyusutan peralatan kantor & 700.000 & \\
\hline Jumlah beban & & ( \\
\hline Laba usaha & & 1 \\
\hline
\end{tabular}

\section{LAPORAN PERUBAHAN MODAL}

\begin{tabular}{|l|l|}
\hline $\begin{array}{l}\text { Modal tuan shah 1 } \\
\text { desember 2016 }\end{array}$ & 150.000 .000 \\
\hline Laba bersih 2016 & $\underline{13.350 .000}$ \\
\hline & 163.350 .000 \\
\hline Pengambilan prive & $(5.000 .000)$ \\
\hline Modal Tuan shah & 158.350 .000 \\
\hline
\end{tabular}


11. Dari data dibawah ini buatlah jurnal koreksi dengan metode dua langkah dan satu langkah!

v. Pada tanggal 4 mei CV. Cahaya membeli secara tunai perlengkapan kantor sebesar 600.000 tetapi dicatat oleh bagian akuntansi sebagai peralatan

VI. Pada tanggal 6 Mei CV. Cahaya memperoleh penghasilan usaha Rp. 24.000 .000 secara tunai tetapi oleh bagian akuntansi dicatat sebesar 12.000 .000

12. Dari data dibawah Buatlah jurnal umum dan jurnal penyesuaian ( tutup buku tanggal 31 Desember 2018) dari transaksi dibawah ini!

G. Pada tanggal 1 April 2018 PT YC memperoleh pendapatan sewa sebesar Rp. 1.200.000 ( dengan pendekatan neraca)

H. Pada tanggal 1 Maret 2018 PT YC membayar biaya iklan untuk 1 tahun sebesar RP. 12.000 .000 (dengan pendekatan laba rugi)

I. PT YC belum membayar gaji pegawai sebesar RP. 4.000 .000 yang seharusnya sudah dibayarkan

5. Berikut ini informasi saldo akun-akun di PT. Jaya Abadi per 31 Desember 2018.

\begin{tabular}{|l|l|}
\hline Kas & $1,700,000$ \\
\hline & \\
Piutang usaha & $1,250,000$ \\
\hline Perlengkapan kantor & \\
\hline
\end{tabular}




\begin{tabular}{|l|l|}
\hline & 50,000 \\
\hline Beban sewa dibayar dimuka & 200,000 \\
\hline Kendaraan & $5,000,000$ \\
\hline Utang usaha & $1,200,000$ \\
\hline & $2,500,000$ \\
\hline Modal & $5,000,000$ \\
\hline Pendapatan & $2,440,000$ \\
\hline Beban iklan & 40,000 \\
\hline Beban gaji & 500,000 \\
\hline
\end{tabular}

Informasi untuk pencatatan penyesuaian per 31 Desember 2018:

k. Hasil perhitungan fisik diketahui bahwa perlengkapan kantor yang masih di gudang bernilai Rp. 10.000

I. Besarnya beban penyusutan peralatan kantor untuk periode 2018 ditetapkan sebesar Rp. 100.000

m. Sewa kantor yang pembayarannya dilakukan dimuka (lihat akun beban sewa dibayar dimuka pada daftar saldo diatas) merupakan transaksi tanggal 2 Juli 2018 untuk penyewaan selama 1 tahun.

n. Besarnya beban penyusutan kendaraan sebesar RP. 500.000

o. Perusahaan harus mengakui beban iklan Rp. 100.000 yang belum dibayarkan tetapi iklan sudah ditayangkan di mperiode ini

Dari data diatas buatlah: 
1. Jurnal penyesuaian

2. Neraca saldo setelah penyesuain dan laporan laba rugi

13. Dari transaksi dibawah ini buatlah persamaan dasar akuntansi

\begin{tabular}{|l|l|}
\hline Tanggal & Keterangan \\
\hline 1 Jan & $\begin{array}{l}\text { PT. ABC memperoleh uang tunai sebesar Rp. } \\
60.000 .000 \text { dari pemilik untuk seteron modal }\end{array}$ \\
\hline 3 Jan & $\begin{array}{l}\text { PT. ABC membeli tunai kendaraan RP. } \\
20.000 .000 \text { secara tunai }\end{array}$ \\
\hline 4 Jan & $\begin{array}{l}\text { PT. ABC membeli perlengkapan secara kredit } \\
\text { sebesar Rp. 1.000.000 kepada UD. Makmur }\end{array}$ \\
\hline 5 Jan & $\begin{array}{l}\text { PT. ABC memperoleh penghasilan RP. } \\
5.000 .000 \text { dari penyewaan kendaraan ke } \\
\text { pelanggan }\end{array}$ \\
\hline 6 Jan & $\begin{array}{l}\text { PT. ABC melunasi semua hutang kepada UD. } \\
\text { Makmur (lihat transaksi tanggal 4) }\end{array}$ \\
\hline 10 Jan & $\begin{array}{l}\text { PT. ABC membayar tagihan listrik sebesar Rp. } \\
500.000\end{array}$ \\
\hline
\end{tabular}

14. Dari data dibawah ini buatlah jurnal penutup dan jelaskan fungsi jurnal penutup!

\section{Perusahaan SHAH, Sidoarjo \\ LAPORAN LABA/ RUGI \\ 31 DESEMBER 2016}

\begin{tabular}{|l|l|l|}
\hline Pendapatan usaha & & \\
\hline Pendapatan jasa & & 27.000 .000 \\
\hline Beban perjalanan dinas & 10.000 .000 & \\
\hline Beban iklan & 900.000 & \\
\hline Beban telepon & 600.000 & \\
\hline
\end{tabular}




\begin{tabular}{|l|l|l|}
\hline Beban listrik dan air & 400.000 & \\
\hline Beban Perlengkapan Kantor & 600.000 & \\
\hline Beban sewa & 450.000 & \\
\hline Beban penyusutan peralatan kantor & 700.000 & \\
\hline Jumlah beban & & $(13.650 .000)$ \\
\hline Laba usaha & & 13.350 .000 \\
\hline
\end{tabular}

LAPORAN PERUBAHAN MODAL

\begin{tabular}{|l|l|}
\hline $\begin{array}{l}\text { Modal tuan shah 1 desember } \\
2016\end{array}$ & 150.000 .000 \\
\hline Laba bersih 2016 & $\underline{13.350 .000}$ \\
\hline & 163.350 .000 \\
\hline Pengambilan prive & $(5.000 .000)$ \\
\hline Modal Tuan shah & 158.350 .000 \\
\hline
\end{tabular}

15. Dari data dibawah ini buatlah jurnal koreksi dengan metode dua langkah dan satu langkah!

VII. Pada tanggal 4 mei CV. Cahaya membeli secara tunai perlengkapan kantor sebesar 600.000 tetapi dicatat oleh bagian akuntansi sebagai peralatan

VIII. Pada tanggal 6 Mei CV. Cahaya memperoleh penghasilan usaha Rp. 24.000.000 secara tunai tetapi oleh bagian akuntansi dicatat sebesar 12.000 .000

16. Dari data dibawah Buatlah jurnal umum dan jurnal penyesuaian ( tutup buku tanggal 31 Desember 2018) dari transaksi dibawah ini!

J. Pada tanggal 1 April 2018 PT YC memperoleh pendapatan sewa sebesar Rp. 1.200 .000 ( dengan pendekatan neraca) 
K. Pada tanggal 1 Maret 2018 PT YC membayar biaya iklan untuk 1 tahun sebesar RP. 12.000.000 (dengan pendekatan laba rugi)

L. PT YC belum membayar gaji pegawai sebesar RP. 4.000.000 yang seharusnya sudah dibayarkan

5. Berikut ini informasi saldo akun-akun di PT. Jaya Abadi per 31 Desember 2018.

\begin{tabular}{|l|l|}
\hline Kas & $1,700,000$ \\
\hline Piutang usaha & $1,250,000$ \\
\hline Perlengkapan kantor & 50,000 \\
\hline Beban sewa dibayar dimuka & 200,000 \\
\hline Kendaraan & $5,000,000$ \\
\hline Peralatan kantor & $1,200,000$ \\
\hline Utang usaha & $2,500,000$ \\
\hline Modal & $5,000,000$ \\
\hline Pendapatan & $2,440,000$ \\
\hline Beban iklan & 40,000 \\
\hline Beban gaji & 500,000 \\
\hline
\end{tabular}


Informasi untuk pencatatan penyesuaian per 31 Desember 2018:

p. Hasil perhitungan fisik diketahui bahwa perlengkapan kantor yang masih di gudang bernilai Rp. 10.000

q. Besarnya beban penyusutan peralatan kantor untuk periode 2018 ditetapkan sebesar Rp. 100.000

r. Sewa kantor yang pembayarannya dilakukan dimuka (lihat akun beban sewa dibayar dimuka pada daftar saldo diatas) merupakan transaksi tanggal 2 Juli 2018 untuk penyewaan selama 1 tahun.

s. Besarnya beban penyusutan kendaraan sebesar RP. 500.000

t. Perusahaan harus mengakui beban iklan Rp. 100.000 yang belum dibayarkan tetapi iklan sudah ditayangkan di mperiode ini

Dari data diatas buatlah:

3. Jurnal penyesuaian

4. Neraca saldo setelah penyesuain dan laporan laba rugi

17. Dari transaksi dibawah ini buatlah persamaan dasar akuntansi

\begin{tabular}{|l|l|}
\hline Tanggal & Keterangan \\
\hline 1 Jan & $\begin{array}{l}\text { PT. ABC memperoleh uang tunai sebesar Rp. } \\
60.000 .000 \text { dari pemilik untuk seteron modal }\end{array}$ \\
\hline 3 Jan & $\begin{array}{l}\text { PT. ABC membeli tunai kendaraan RP. } \\
20.000 .000 \text { secara tunai }\end{array}$ \\
\hline 4 Jan & $\begin{array}{l}\text { PT. ABC membeli perlengkapan secara kredit } \\
\text { sebesar Rp. 2.500.000 kepada UD. Makmur }\end{array}$ \\
\hline 5 Jan & $\begin{array}{l}\text { PT. ABC memperoleh penghasilan RP. } \\
5.000 .000 \text { dari penyewaan kendaraan ke } \\
\text { pelanggan }\end{array}$ \\
\hline 8 Jan & $\begin{array}{l}\text { PT. ABC melunasi semua hutang kepada UD. } \\
\text { Makmur (lihat transaksi tanggal 4) }\end{array}$ \\
\hline 10 Jan & $\begin{array}{l}\text { PT. ABC membayar tagihan listrik sebesar Rp. } \\
500.000\end{array}$ \\
\hline
\end{tabular}


Rp. 4.000 .000

18. Dari data dibawah ini buatlah jurnal penutup dan jelaskan fungsi jurnal penutup!

\section{Perusahaan SHAH, Sidoarjo \\ LAPORAN LABA/ RUGI \\ 31 DESEMBER 2016}

\begin{tabular}{|l|l|}
\hline Pendapatan usaha & \\
\hline Pendapatan jasa & \\
\hline Beban perjalanan dinas & 10.000 .000 \\
\hline Beban iklan & 900.000 \\
\hline Beban telepon & 600.000 \\
\hline Beban listrik dan air & 400.000 \\
\hline Beban Perlengkapan Kantor & 600.000 \\
\hline Beban sewa & 450.000 \\
\hline Beban penyusutan peralatan kantor & 700.000 \\
\hline Jumlah beban & \\
\hline Laba usaha & \\
\hline
\end{tabular}

LAPORAN PERUBAHAN MODAL

\begin{tabular}{|l|l|}
\hline $\begin{array}{l}\text { Modal tuan shah 1 desember } \\
2016\end{array}$ & 150.000 .000 \\
\hline Laba bersih 2016 & $\underline{13.350 .000}$ \\
\hline & 163.350 .000 \\
\hline Pengambilan prive & $(5.000 .000)$ \\
\hline Modal Tuan shah & 158.350 .000 \\
\hline
\end{tabular}

19. Dari data dibawah ini buatlah jurnal koreksi dengan metode dua langkah dan satu langkah!

IX. Pada tanggal 4 mei CV. Cahaya membeli secara tunai perlengkapan kantor sebesar 200.000 tetapi dicatat oleh bagian akuntansi sebagai peralatan 
X. Pada tanggal 6 Mei CV. Cahaya memperoleh penghasilan usaha Rp. 24.000 .000 secara tunai tetapi oleh bagian akuntansi dicatat sebesar 12.000 .000

20. Dari data dibawah Buatlah jurnal umum dan jurnal penyesuaian ( tutup buku tanggal 31 Desember 2018) dari transaksi dibawah ini!

M. Pada tanggal 1 April 2018 PT YC memperoleh pendapatan sewa sebesar Rp. 1.200.000 ( dengan pendekatan neraca)

N. Pada tanggal 1 Maret 2018 PT YC membayar biaya iklan untuk 1 tahun sebesar RP. 12.000.000 (dengan pendekatan laba rugi)

O. PT YC belum membayar gaji pegawai sebesar RP. 4.000.000 yang seharusnya sudah dibayarkan

5. Berikut ini informasi saldo akun-akun di PT. Jaya Abadi per 31 Desember 2018.

\begin{tabular}{|l|l|}
\hline Kas & $1,700,000$ \\
\hline Piutang usaha & $1,250,000$ \\
\hline Perlengkapan kantor & 50,000 \\
\hline Beban sewa dibayar dimuka & 200,000 \\
\hline Kendaraan & $5,000,000$ \\
\hline & \\
\hline Peralatan kantor & $1,200,000$ \\
\hline
\end{tabular}




\begin{tabular}{|l|l|}
\hline Utang usaha & $2,500,000$ \\
\hline Modal & $5,000,000$ \\
\hline Pendapatan & $2,440,000$ \\
\hline Beban iklan & 40,000 \\
\hline Beban gaji & 500,000 \\
\hline
\end{tabular}

Informasi untuk pencatatan penyesuaian per 31 Desember 2018:

u. Hasil perhitungan fisik diketahui bahwa perlengkapan kantor yang masih di gudang bernilai Rp. 10.000

v. Besarnya beban penyusutan peralatan kantor untuk periode 2018 ditetapkan sebesar Rp. 100.000

w. Sewa kantor yang pembayarannya dilakukan dimuka (lihat akun beban sewa dibayar dimuka pada daftar saldo diatas) merupakan transaksi tanggal 2 Juli 2018 untuk penyewaan selama 1 tahun.

x. Besarnya beban penyusutan kendaraan sebesar RP. 500.000

y. Perusahaan harus mengakui beban iklan Rp. 100.000 yang belum dibayarkan tetapi iklan sudah ditayangkan di mperiode ini

Dari data diatas buatlah:

1. Jurnal penyesuaian

2. Neraca saldo setelah penyesuain dan laporan laba rugi

\section{Daftar Pustaka}


Keiso, Donald E. Weygandt, Jerry J. Warfield, Terry D. 2007. Akuntansi Intermediate. Penerbit Erlangga. Jakarta.

Martani, Dwi. Dkk. 2016. Akuntansi Keuangan Menengah. Salemba Empat. Jakarta

Niswonger, C. Rollin. Warren, Carls S. Reeve, James M. 1999. Prinsip-Prinsip Akuntansi Edisi 19. Penerbit Erlangga. Jakarta 


\section{AKUNTANSI}

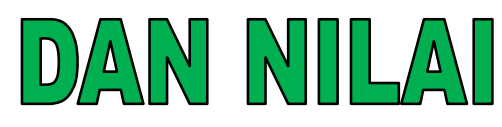

\section{WAKTU}

\section{DARI UANG}

TUJUAN PEMBELAJARAN

Setelah mempelajari bab ini, Anda diharapkan mampu:

1. Membandingkan bunga majemuk dan bunga sederhana

2. Memahami soal nilai masa depan dan nilai sekarang

3. Memahami soal nilai sekarang dari anuitas biasa dan jatuh tempo

\section{BAB V}




\section{AKUNTANSI DAN NILAI WAKTU DARI UANG}

\section{Pendahuluan}

Anda mengethui bahwa uang yang anda miliki saat ini mempunyai nilai lebih kecil dibandingkan dengan tahuntahun sebelumnya. Misalnya untuk membeli gula hanya Rp. 7.000 akan tetapi satu kilo gula pada saat ini menjadi Rp. 11.000 hal tersebut artinya nilai nominal dimasa lalu mempunyai nilai yang berbeda pada saat sekarang.

\section{Konsep dari Nilai Waktu Dasar}

Time value of money atau yang disebut dengan nilai waktu dari uang adalah suatu hubngan antara uang dan waktu, artinya adalah bahwa jika perusahaan hari ini menerima 1 rupiah akan lebih berharga daripada perusahaan menerima 1 rupiah di masa yang akan datang. Misalnya perusahaan melakukann investasi deposito perusahaan akan membandingkan nilai rupiah hari ini dengan nilai rupiah pada masa yang akan datang.

\section{Sifat Bunga}

Bunga (interest) merupakan imabalan atau pembayaran untuk pemakaian uang. Bunga adalah kas yang diterima 
perusahaan ataupun dibayarkan kembali oleh perusahaan di atas jumlah pokok pinjaman (principal).

Variabel-varibel dalam perhitungan bunga

1. Pokok Utang (Principal) : Yaitu jumlah yang dipinjam atau di investasikan

2. Suku Bunga (Interest Rate) : Yaitu presentase tertentu dari suatu pokok hutang yang beredar.

3. Waktu ( Time) : jumlah tahunan

\section{Bunga Sederhana}

Bunga sederhana merupakan jumlah bunga yang perhitungannya terhadap jumlah pokok pinjamannya.

\section{Bunga $=$ p $x$ i $\times$ n}

Keterangan :
$\mathrm{P} \quad=$ Pokok
I = Suku Bunga
$\mathrm{N} \quad=$ Jumlah Periode

Contoh: 
Ilustrasi: PT. AZKI. Mempunyai pinjaman sebesar Rp 5.000 dan untuk jangka waktu 5 tahun, bunga 10\% per tahun, Total bunga yang harus dibayar oleh PT. Azki adalah sebesar:

$$
\text { Bunga } \begin{aligned}
& =\mathrm{p} \times \mathrm{i} \times \mathrm{n} \\
& =\text { Rp. } 5.000 \times 0,10 \times 5 \\
= &
\end{aligned}
$$

\section{Bunga Majemuk}

Bunga Majemuk merupakan perhitungan bunga yang dihitung dari suatu pokok pinjaman dan ditambahkan bunga dari bunga yang sudah dibayarkan pada periode sebelumnya.

Ilustrasi: PT. Azki mendepositokan Rp. 20.000 pada Bank AZK, yang akan membayar bunga sederhana $10 \%$ per tahun. Pt. Azki kemudian mendepositokan Rp. 20.000 lagi pada Bank AZK, yang akan membayar bunga majemuk $10 \%$ per tahun, yang dimajemukkan secara tahunan. Juga diasumsikan bahwa Azki tidak akan menarik setiap bunga sampai 5 tahun dari tanggal deposit dilakukan maka perhitungan sebagai berikut:

\section{Tabel Bunga Majemuk}

1. Tabel Nilai Masa Depan dari 1 : Berisi jumlah sebesar 1 yang akan terakumulasi jika didepositokan sekarang pada suku bunga tertentu dan disimpan sepanjang periode tertentu. 
2. Tabel Nilai Sekarang dari 1 : Berisi jumlah nilai yang harus didepositokan sekarang pada suku bunga tertentu agar sama dengan 1 pada akhir periode tertentu.

3. Tabel Nilai Masa Depan dari Anuitas Biasa Sebesar 1 : Berisi jumlah di mana sewa periodik sebesar 1 akan terakumulasi jika pembayaran tersebut diinvestasikan pada setiap akhir interval periodik reguler sepanjang sejumlah periode tertentu.

4. Tabel Nilai Masa Sekarang dari Anuitas Biasa Sebesar 1 : Berisi nilai yang harus didepositokan sekarang pada suku bunga tertentu agar bisa ditarik sebesar 1 pada akhir interval periodik reguler sepanjang sejumlah periode tertentu.

5. Tabel Nilai Masa Sekarang dari Anuitas Jatuh Tempo Sebesar 1 : Berisi nilai yang harus didepositokan sekarang pada suku bunga tertentu agar bisa ditarik sebesar 1 pada awal interval periodik reguler sepanjang sejumlah periode tertentu.

Rumus untuk menghitung Future Value

FVF $n, \mathrm{i}=$ faktor nilai masa depan untuk periode $\mathrm{n}$ dan $\mathrm{i}$ pada bunga

$$
\begin{array}{ll}
\mathrm{n}= & \text { jumlah periode } \\
\mathrm{i} & =\text { suku bunga untuk satu periode }
\end{array}
$$

\section{Varibel-variabel Dasar}


Empat variabel dasar bagi masalah bunga majemuk antara lain:

1. Suku bunga : Merupakan suku bunga tahunan,

2. Jumlah periode waktu : Adalah jumlah periode pemajemukkan

3. Nilai masa depan :Nilai pada masa depan dari jumlah

4. Nilai sekarang : adalah nilai sekarang merupakan dari suatu jumlah di masa depan

\section{Masalah Jumlah Tunggal}

Jumlah tunggal ada beberapa masalah yang secara umum bisa dijadikan kedalam kelompok yaitu menjadi dua kategori,sebagai berikut:

1. Pada masa yang akan datang perhitungannya tidak diketehui dari jumlah uang tunggal untuk investasi saat ini untuk periode dan suku bungan tertentu.

2. Perhitungan nilai saat ini yang tidak diketahui dari suatu jumlah uang tunggal di masa yang akan datang selama periode tertentu pada suatu suku bunga tertentu pula.

\section{Nilai Masa Depan dari Jumlah Tunggal}

Menentukan nilai di masa depan dari jumlah tunggal, dengan mengalikan factor nilai yang akan datang dengan nilai saat ini (pokok) dengan rumus sebagai berikut:

$$
\mathbf{F V}=\quad \mathbf{P V}(\mathbf{F V F} \mathbf{n}, \mathbf{I})
$$


$\mathrm{FV} \quad=$ nilai masa depan

PV = nilai sekarang

FVF $n, i=$ faktor nilai saat ini bagi $n$ periode (tahun) pada suatu suku bunga tertentu $\mathrm{i}$

\section{Nilai Sekarang dari Jumlah Tunggal}

Jumlah nilai yang mesti diinvestasikan saat ini agar menghasilkan nilai masa depan yang diketahui sebelumnya.Rumusnya :

PVF $n, i=1 /(1+i) n$

$P V=F V(P V F n, I)$

Contoh : berapa nilai sekarang dari Rp. 100.000 dengan bunga 11\% yang akan diterima dalam 5 tahun?

$$
P V \quad=F V(P V F n, I)
$$


$5,11 \%$ )

$=\quad$ Rp.

$100.000(1 /(1+0,11) 5)$

$=70.000$

\section{Menghitung Variabel Lain Yang Belum Diketehui}

Suku bunga (i) atau suku bunga ( $\mathrm{n}$ ) yang belum diketahui merupakan variable lain yang dimaksud disini. Variabel tersebut bisa dicari jika tiga variable dasar dari empat variable sudah diketahui.

$\checkmark$ Perhitungan jumlah periode

Misalnya, PT. Azki ingin mempunyai dana sebesar 80.000.000, Pt azki mendepositokan uang sebesar Rp. 100.000 dengan bunga 10\% Berapa tahun agar uang itu bisa menjadi Rp. 80.000 .000 ?

Dengan menggunakan pendekatan masa depan, maka :

$$
F V=P V(F V F n, i)
$$

$$
\begin{array}{ll}
80.000 .000 & =100.000(\text { FVF } n, 10 \%) \\
\text { FVFn, } 10 \% & =80.000 .000 / 100.000
\end{array}
$$

$=1,46410$, dengan melihat table bunga maka dapat diketahui jika waktu yang dibutuhkan adalah 8 tahun. 


\begin{abstract}
Perhitungan suku bunga
Untuk menghitung suku bunga mempunyai cara yang sama dengan menghitung jumlah periode, dengan cara menggunakan pendekatan nilai sekarang atau nilai masa depan. Dengan cara hasil PV dengan FV, atau FV dengan PV bisa melihat tabel bunga untuk mengetahui besarnya suku bunga.
\end{abstract}

\title{
Anuitas
}

Anuitas merupakan pembayaran atau penerimaan yang mempunyai jumlah yang tetap dan dilakukan dengan jangka waktu yang berkala.

1. Pada setiap periode selalu mempunyai jumlah yang sama untuk penerimaan atau pembayaran.

2. Mempunyai jangka waktu yang sama antara pembayaran maupun sewa.

3. Bunga dimajemukkan sekali setiap interval. Anuitas dibedakan menjadi 2, yaitu:

a. Anuitas biasa terjadi apabila sewa tersebut terjadi di setiap akhir periode.

b. Anuitas jatuh tempo terjadi apabila sewa tersebut terjadi di setiap awal periode.

\section{Nilai Masa Depan dari Anuitas Biasa}


Pendekatan yang dilakukan dengan menghitung nilai pembayaran yang terakumulasi untuk menentukan nilai masa depan anuitas.

$$
\text { FVF-0An, } \mathrm{I}=\quad(1+\mathrm{i}) \mathrm{n}-1 / \mathrm{i}
$$

Keterangan

$$
\begin{aligned}
& \text { FVF-OAn,I }=\text { factor nilai masa depan dari suatu anuitas biasa } \\
& \begin{aligned}
\mathrm{I} & =\text { suku bunga per periode } \\
\mathrm{n} & =\text { jumlah periode pemajemukan }
\end{aligned}
\end{aligned}
$$

\section{Nilai Masa Depan Dari Anuitas}

\section{$\mathrm{R}(\mathrm{FVF}-\mathrm{AAn}, \mathrm{I})$}

Keterangan :

$\mathrm{R}=$ = pembayaran periodik

Nilai Masa Depan dari Anuitas Jatuh Tempo 
Anuitas jatuh tempo diasumsikan bahwa pembayaran terjadi pada setiap periode dilakukan diawal periode. Anuitas jatuh tempo. Selama periode pertama bunga akan diakumulasikan. Faktor nilai masa depan dari anuitas jatuh tempo dapat dihitung dengan mengalikan faktor nilai masa depan dari anuitas biasa dengan dengan 1 ditambah suku bunga.

Anuitas jatuh tempo pada setiap awal

\section{Nilai Sekarang dari Anuitas Biasa}

Nilai sekarang dari anuitas biasa adalah nilai sekarang dari serangkaian jumlah yang sama untuk diterima pada interval yang sama pula. Nilai sekarang dari anuitas biasa dapat dihitung dengan cara :

Nilai Sekarang dari Anuitas Biasa $=\mathrm{R}(\mathrm{PVF}-\mathrm{OA} \mathrm{n}, \mathrm{i})$

\section{Nilai Sekarang dari Anuitas Jatuh Tempo}

Dalam menentuan nilai sekarang dari anuitas jatuh tempo, terdapat periode diskonto yang kurang dari 1. Faktor nilai sekarang dari anuitas jatuh tempo dihitung dengan mengalikan faktor nilai dari anuitas biasa dengan 1 ditambah suku bunga 


\section{Situasi yang lebih kompleks}

Dua situasi umum dalam situasi kompleks yang telah disebutkan sebelumnya antara lain:

\section{Penilaian obligasi jangka panjang}

Pada penilaian obligasi jangka panjang akan menghasilkan dua arus kas yaitu :

- Pembayaran bunga periodik

- Nilai nominal (single-sum) saat jatuh tempo.

\section{Amortisasi diskonto atau premi obligasi bunga efektif}

Metode yang dianjurkan untuk amortisasi premi atau amortisasi diskonto adalah metode bunga efektif.

Metode amortisasi diskonto atau premi obligasi dengan bunga efektif :

- $\quad$ Pertama, beban bunga = nilai buku obligasi $X$ suku bunga efektif

- Kedua, amortisasi dihitung dengan membandingkan beban bunga obligasi dengan bunga yang harus dibayar.

\section{Kesimpulan}


Tabel Nilai Masa Depan dari 1 : Berisi jumlah sebesar 1 yang akan terakumulasi jika didepositokan sekarang pada suku bunga tertentu dan disimpan sepanjang periode tertentu. Tabel Nilai Sekarang dari 1 : Berisi jumlah nilai yang harus didepositokan sekarang pada suku bunga tertentu agar sama dengan 1 pada akhir periode tertentu. Tabel Nilai Masa Depan dari Anuitas Biasa Sebesar 1 : Berisi jumlah di mana sewa periodik sebesar 1 akan terakumulasi jika pembayaran tersebut diinvestasikan pada setiap akhir interval periodik reguler sepanjang sejumlah periode tertentu. Tabel Nilai Masa Sekarang dari Anuitas Biasa Sebesar 1 : Berisi nilai yang harus didepositokan sekarang pada suku bunga tertentu agar bisa ditarik sebesar 1 pada akhir interval periodik reguler sepanjang sejumlah periode tertentu. Tabel Nilai Masa Sekarang dari Anuitas Jatuh Tempo Sebesar 1 : Berisi nilai yang harus didepositokan sekarang pada suku bunga tertentu agar bisa ditarik sebesar 1 pada awal interval periodik reguler sepanjang sejumlah periode tertentu. Anuitas jatuh tempo diasumsikan bahwa pembayaran terjadi pada setiap periode dilakukan diawal periode. Anuitas jatuh tempo. Selama periode pertama bunga akan diakumulasikan. Faktor nilai masa depan dari anuitas jatuh tempo dapat dihitung dengan mengalikan faktor nilai masa depan dari anuitas biasa dengan dengan 1 ditambah suku bunga. Anuitas jatuh tempo pada setiap awal. Nilai sekarang dari anuitas biasa adalah nilai sekarang dari serangkaian jumlah yang sama untuk diterima pada interval yang sama pula. 
LATIHAN SOAL

A. Asumsikan bahwa PT. Royal memutuskan untuk mendepositokan Rp. 2.000.000,-pada akhir dari setiap periode 6 bulan selama 5 Tahun berikutnya. Berapa nilai masa depan dalam deposito ini pada akhir 5 tahun jika suku bunga $12 \%$

B. Anggaplah perusahaan Anda ingin mengumpulkan RP. 28.637.500,-pada akhir setiap tahun sebesar Rp. 500.000,- yang akan menghasilan $10 \%$ yang dimajemukan secara tahunan. Berapa kali deposito yang harus Anda lakukan?

C. Asumsikan bahwa PT. Azzhra memutuskan untuk mendepositokan Rp. 4.000.000,-pada akhir dari setiap periode 6 bulan selama 4 Tahun berikutnya. Berapa nilai masa depan dalam deposito ini pada akhir 4 tahun jika suku bunga $10 \%$

D. Anggaplah perusahaan Anda ingin mengumpulkan RP. 38.126.976,- pada akhir setiap tahun sebesar Rp. 1.200.000,- yang akan menghasilan $10 \%$ yang dimajemukan secara tahunan. Berapa kali deposito yang harus Anda lakukan?

E. Berapa nilai sekarang dari Rp. 359.172 yang akan dibayarkan dalam 12 tahun jika didiskontokan 5\% yang dimajemukan secara tahunan? 
F. Asumsikan bahwa PT. Azzhra memutuskan untuk mendepositokan Rp. 4.000.000,-pada akhir dari setiap periode 6 bulan selama 4 Tahun berikutnya. Berapa nilai masa depan dalam deposito ini pada akhir 4 tahun jika suku bunga $10 \%$

G. Anggaplah perusahaan Anda ingin mengumpulkan RP. 38.126.976,- pada akhir setiap tahun sebesar Rp. 1.200.000,- yang akan menghasilan $10 \%$ yang dimajemukan secara tahunan. Berapa kali deposito yang harus Anda lakukan?

\section{Daftar Pustaka}

Keiso, Donald E. Weygandt, Jerry J. Warfield, Terry D. 2007. Akuntansi Intermediate. Penerbit Erlangga. Jakarta.

Martani, Dwi. Dkk. 2016. Akuntansi Keuangan Menengah. Salemba Empat. Jakarta

Niswonger, C. Rollin. Warren, Carls S. Reeve, James M. 1999. Prinsip-Prinsip Akuntansi Edisi 19. Penerbit Erlangga. Jakarta 

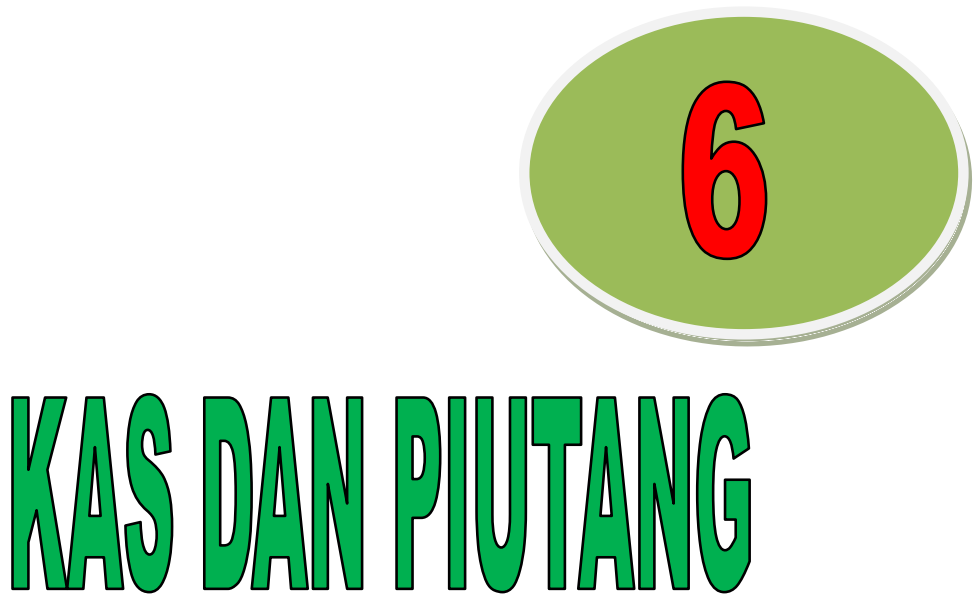

TUJUAN PEMBELAJARAN

Setelah mempelajari bab ini, Anda diharapkan mampu:

1. Menjelaskan tentang kas

2. Menielaskan tentang piutang 


\section{BAB VI}

\section{KAS DAN PIUTANG}

\section{Pendahuluan}

Kas dan piutang merupakan unsure yang penting bagi perusahaan, karena kas berperan penting untuk berjalannya operasional perusahaan. Pendapatan ada yang berupa tunai atau piutang.

\section{Kas}

Kas merupakan sebuah aktiva dari keuangan, semua mata uang kertas dan logam, baik mata uang asing maupun mata uang dalam negeri, dan semua surat-surat berharga yang mempunyai sifat sifat seperti uang, yaitu yang bisa segera 
dicairkan atau dipergunakan untuk melakukan pembayaranpembayaran pada setiap waktu. Kas merupakan aktiva yang paling likuid.

Berdasarkan Pengertian diatas maka yang termasuk dalam kas yang termasuk dalam unsur current aset yaitu:

1. Mata Uang yaitu Logam maupun kertas yang diterbitkan oleh pemerintah.

2. Mata uang asing, logam maupun kertas yang diterbitkan oleh Negara lain

3. Bank notes yaitu mata uang kertas atau logam yang diterbitkan oleh Bank ( Bank Indonesia)

4. Demand Deposit yaitu simpanan uang di bank yang bisa diambil sewaktu-waktu

\section{Pelaporan Kas}

Berikut merupakan masalah-masalah yang berhubungan dengan pelaporan kas: Masalah-masalah yang ada hubungannya dengan pelaporan kas adalah : Ekuivalen kas, Overdraft bank dan Kas yang dibatasi .

\section{Ekuivalen Kas}

Ekuivalen kas merupakan suatu investasi yang berjangka pendek, sangat lancer. Investasi yang sangat lancar dan mempunyai jangka waktu yang pendek sehingga kalau ada 
perubahan suku bunga tidak berpengaruh secara signifikan terhadap ekuivalen kasn dan bisa segera dikonversikan menjadi kas.

\section{Kas yang Dibatasi atau Restriktif}

Kas yang dibatasi (restricted cash) termasuk kedalam aktiva jangka panjang atau Aktiva Lancar, Kas ini dilasifikasikan dalam kelompok aktiva lancar apabila kas akan dipakai untuk melakukan pembayaran terhadap kewajiban perusahaan atau jatuh tempo. Di sisi lain, jika kas dipegang untuk periode waktu yang lama, maka kas yang dibatasi ditampilkan dalam kelompok jangka panjang dari neraca.

Contoh: Pelunasan hutang jangka panjang dan pencatatan biaya deposito.

\section{Overdraft Bank}

Cek yang ditulis dengan nilai nominal tertentu yang kemudian melebihi rekening kas punya perusahaan.

\section{Ikhtisar Pos-pos yang Berhubungan dengan Kas}

\section{Piutang}

Piutang (receivables) Adalah ada sejumlah nilai yang dihutang oleh pelanggan dimana perusahaan sudah 
memberikan jasa atau barang kepada pelanggan tersebut atau pihak lain.

Piutang Dagang, Piutang dagang (trade receivables) adalah sejumlah jasa maupun barang yang terhutang oleh pelanggan, di mana barang ataupun jasa itu telah diberikan oleh perusahaan kepada pelanggan di masa lalu . Piutang ini selanjutnya disubklasifikasikan menjadi 2, yaitu:

Piutang dagang maupun Piutang usaha atau yang biasa disebut sebagai accounts receivable merupakan janji pembeli untuk melunasi hutangnya atas barang atau jasa yang sudah diterima oleh pembeli.

Wesel Tagih, Wesel tagih atau yang biasa disebut sebagai note receivable yaitu merupakan janji yang tertulis dari pelanggan kepada perusahaan untuk membayar pada tanggal tertentu dan sejumlah uang di masa yang akan datang untuk melunasi. Jatuh tempo wesel tagih bisa jatuh tempo jangka pendek ataupun jangka panjang.

\section{Pengakuan Piutang Usaha}

Diskon Dagang merupakan sejumlah potongan dari daftar harga, tidak dicatat dalam akuntansi, dan akan ditagihkan kepada pelanggan sejumlah harga bersihnya dari diskon.

\section{Diskon Tunai}


Ada dua metode yaitu yaitu metode kotor dan metode bersih.

\section{Piutang Usaha Tak Tertagih}

Dengan adanya penjualan kredit akan menimbulkan resiko adanya suatu kegagalan perusahaan untuk menagih piutang. Terdapat dua metode dalam pencatatan pengakuan piutang tak tertagih, yaitu:

- Metode Penghapusan Langsung

Perusahaan tidak mencatat jurnal apapun yang berhubungan dengan mengahapus piutang tidak tertagih, kerugian perusahaan dijurnal dengan cara piutang usaha dikredit dan beban piutang tak tertagih didebit.

- Metode Penyisihan

Perusahaan membuat estimasi yang berasal dari seluruh penjualan kredit atau total piutang yang beredar pada pelanggan. Estimasi ini selanjutnya dicatat sebagai beban dan pengurang yang secara tidak langsung mengurangi piutang usaha perusahaan di periode di mana penjualan tersebut dicatat. Estimasi jumlah piutang tak tertagih ini biasanya dibuat atas dasar:

Ilustrasi

PT. Azki mengestimasikan bahwa sekitar $2 \%$ dari penjualan kredit tidak akan tertagih. Jika penjualan kredit bersih adalah 
Rp 1.000.000 di tahun 2020, maka pencatatan beban piutang tak tertagih adalah sebagai berikut.

Beban piutang tak tertagih

20. 000

Penyisihan untuk piutang tak tertagih

20.000

\section{Penurunan Nilai Piutang}

- Kegagalan pembayaran

- Negosiasi kembali dari kebijakan piutang karena kesulitan keungan yang dialami oleh pelanggan

- Penurunan estimasi arus kas di masa depan dari sebuah klasifikasi piutang

\section{Wesel Tagih}

\section{Pengakuan Wesel Tagih}

Suatu wesel tagih yaitu merupakan suatu janji yang tertulis untuk melakukan pembayaran sejumlah uang tertentu pada tanggal tertentu di masa yang akan datang.

Kesimpulan

Kas merupakan sebuah aktiva dari keuangan, semua mata uang kertas dan logam, baik mata uang asing maupun mata uang dalam negeri, dan semua surat-surat berharga yang 
mempunyai sifat sifat seperti uang, yaitu yang bisa segera dicairkan atau dipergunakan untuk melakukan pembayaranpembayaran pada setiap waktu. Kas merupakan aktiva yang paling likuid.

Berdasarkan Pengertian diatas maka yang termasuk dalam kas yang termasuk dalam unsur current aset yaitu: Mata Uang yaitu Logam maupun kertas yang diterbitkan oleh pemerintah. Mata uang asing, logam maupun kertas yang diterbitkan oleh Negara lain. Bank notes yaitu mata uang kertas atau logam yang diterbitkan oleh Bank ( Bank Indonesia). Demand Deposit yaitu simpanan uang di bank yang bisa diambil sewaktu-waktu

Berikut merupakan masalah-masalah yang berhubungan dengan pelaporan kas: Masalah-masalah yang ada hubungannya dengan pelaporan kas adalah : Ekuivalen kas, Overdraft bank dan Kas yang dibatasi .

Ekuivalen kas merupakan suatu investasi yang berjangka pendek, sangat lancer. Investasi yang sangat lancar dan mempunyai jangka waktu yang pendek sehingga kalau ada perubahan suku bunga tidak berpengaruh secara signifikan terhadap ekuivalen kasn dan bisa segera dikonversikan menjadi kas.

Soal

1. Dari data dibawah ini susunlah menjadi laporan arus kas metode tidak langsung 


\begin{tabular}{|c|c|}
\hline Laba & 15.000 .000 \\
\hline Beban penyusutan & 500.000 \\
\hline $\begin{array}{l}\text { Amortisasi aktiva tdk } \\
\text { berwujud }\end{array}$ & 200.000 \\
\hline $\begin{array}{l}\text { Keuntungan atas } \\
\text { penjualan mesin pabrik }\end{array}$ & 2.000 .000 \\
\hline Kenaikan piutang & 4.000 .000 \\
\hline $\begin{array}{l}\text { Membeli saham } \\
\text { perusahaan lain (PT. YX) }\end{array}$ & 3.000 .000 \\
\hline $\begin{array}{l}\text { Menerima pembagian } \\
\text { deviden }\end{array}$ & 500.000 \\
\hline Menerbitkan obligasi & 50.000 .000 \\
\hline $\begin{array}{l}\text { Membagi kupon/bunga } \\
\text { obligasi }\end{array}$ & 2.000 .000 \\
\hline
\end{tabular}

2. Pada awal bulan maret, Manajer PT. ABC membentuk dana kas kecil yang akan digunakan untuk membayar pengeluaran-pengeluaran tunai yang tidak besar jumlahnya dan sering terjadi. Disepakati bahwa dana kas kecil yang dibentuk sebesar Rp. 2.000.000 yang akan diisi kembali setiap tgl 10 dn 25 setiap bulannya

selama bulan maret 2016 transaksi PT ABC yang menggunakan kas kecil adalah sebagai berikut:

\begin{tabular}{|l|l|}
\hline Tanggal & Transaksi \\
\hline $2 / 3$ & $\begin{array}{l}\text { Membeli Materai dan } \\
\text { Peerangko sebesar Rp. } \\
300.000\end{array}$ \\
\hline $5 / 3$ & $\begin{array}{l}\text { Membeli bensin, solar dan } \\
\text { minyak sebesar Rp. 200.000 }\end{array}$ \\
\hline $12 / 3$ & Membeli perlengakapan \\
\hline
\end{tabular}




\begin{tabular}{|l|l|}
\hline & kantor sebesar RP. 500.000 \\
\hline $20 / 3$ & $\begin{array}{l}\text { Membayar listrik sebesar } \\
\text { RP. 1.000.000 }\end{array}$ \\
\hline $23 / 3$ & $\begin{array}{l}\text { Membayar telepon Rp. } \\
200.000\end{array}$ \\
\hline $24 / 3$ & $\begin{array}{l}\text { Membayar fotocopi } \\
\text { Rp.100.000 }\end{array}$ \\
\hline
\end{tabular}

Buatlah jurnal umum yang diperlukan untuk penggunaan kas keidl dengan metode imprest dan fluktuasi

Pada awal bulan maret, Manajer PT. ABC membentuk dana kas kecil yang akan digunakan untuk membayar pengeluaran-pengeluaran tunai yang tidak besar jumlahnya dan sering terjadi. Disepakati bahwa dana kas kecil yang dibentuk sebesar Rp. 2.000.000 yang akan diisi kembali setiap tgl 10 dn 25 setiap bulannya selama bulan maret 2016 transaksi PT ABC yang menggunakan kas kecil adalah sebagai berikut:

\begin{tabular}{|l|l|}
\hline Tanggal & Transaksi \\
\hline $2 / 3$ & $\begin{array}{l}\text { Membeli Materai dan } \\
\text { Peerangko sebesar Rp. } \\
200.000\end{array}$ \\
\hline $5 / 3$ & $\begin{array}{l}\text { Membeli bensin, solar dan } \\
\text { minyak sebesar Rp. 100.000 }\end{array}$ \\
\hline $12 / 3$ & $\begin{array}{l}\text { Membeli perlengakapan } \\
\text { kantor sebesar RP. 400.000 }\end{array}$ \\
\hline
\end{tabular}




\begin{tabular}{|l|l|}
\hline $20 / 3$ & $\begin{array}{l}\text { Membayar listrik sebesar } \\
\text { RP. 1.000.000 }\end{array}$ \\
\hline $23 / 3$ & $\begin{array}{l}\text { Membayar telepon Rp. } \\
100.000\end{array}$ \\
\hline $24 / 3$ & $\begin{array}{l}\text { Membayar fotocopi } \\
\text { Rp.100.000 }\end{array}$ \\
\hline
\end{tabular}

Buatlah jurnal umum yang diperlukan untuk penggunaan kas keidl dengan metode imprest

Pada awal bulan maret, Manajer PT. ABC membentuk dana kas kecil yang akan digunakan untuk membayar pengeluaran-pengeluaran tunai yang tidak besar jumlahnya dan sering terjadi. Disepakati bahwa dana kas kecil yang dibentuk sebesar Rp. 2.000.000 yang akan diisi kembali setiap tgl 10 dn 25 setiap bulannya selama bulan maret 2016 transaksi PT ABC yang menggunakan kas kecil adalah sebagai berikut:

\begin{tabular}{|l|l|}
\hline Tanggal & Transaksi \\
\hline $2 / 3$ & $\begin{array}{l}\text { Membeli Materai dan } \\
\text { Perangko sebesar Rp. } \\
100.000\end{array}$ \\
\hline $5 / 3$ & $\begin{array}{l}\text { Membeli bensin, solar dan } \\
\text { minyak sebesar Rp. 20.000 }\end{array}$ \\
\hline $12 / 3$ & $\begin{array}{l}\text { Membeli perlengakapan } \\
\text { kantor sebesar RP. 300.000 }\end{array}$ \\
\hline $20 / 3$ & $\begin{array}{l}\text { Membayar listrik sebesar } \\
\text { RP. 100.000 }\end{array}$ \\
\hline $23 / 3$ & $\begin{array}{l}\text { Membayar telepon Rp. } \\
200.000\end{array}$ \\
\hline $24 / 3$ & $\begin{array}{l}\text { Membayar fotocopi } \\
\text { Rp.100.000 }\end{array}$ \\
\hline
\end{tabular}

Buatlah jurnal umum yang diperlukan untuk penggunaan kas keidl dengan metode fluktuasi 


\section{Daftar Pustaka}

Keiso, Donald E. Weygandt, Jerry J. Warfield, Terry D. 2007. Akuntansi Intermediate. Penerbit Erlangga. Jakarta. 
Martani, Dwi. Dkk. 2016. Akuntansi Keuangan Menengah. Salemba Empat. Jakarta

Niswonger, C. Rollin. Warren, Carls S. Reeve, James M. 1999. Prinsip-Prinsip Akuntansi Edisi 19. Penerbit Erlangga. Jakarta

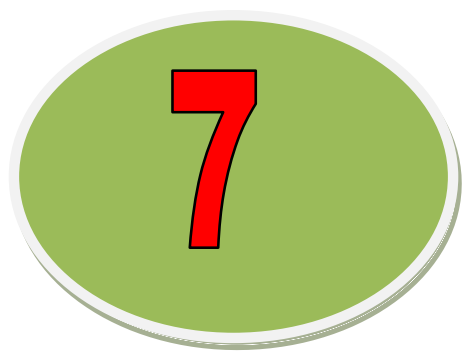




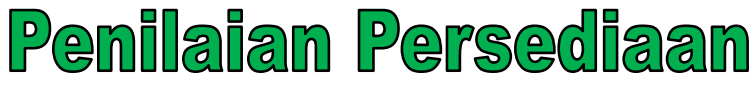

Dasar Büaya

\section{TUJUAN PEMBELAJARAN}

Setelah mempelajari bab ini, Anda diharapkan mampu:

5. Menjelaskan akuntansi dan laporan keuangan

6. Menjelaskan akuntansi dalam alokasi sumber daya

7. Menjelaskan standard akuntansi

\section{BAB VII}




\section{KLASIFIKASI DAN PENGENDALIAN PERSEDIAAN Klasifikasi}

Persediaan (inventory) Merupakan harta perusahaan yang akan digunakan untuk memproduksi barang jadi atau barang yang siap untuk dijual.

Perusahaan dagang akan membeli barang dagang dalam bentuk yang siap untuk dijual. Perusahaan dagang akan mencatat barang yang belum terjual sebagai persediaan barang dagang. Perusahaan manufaktur akan menjual hasil produksinya kepada perusahaan dagang. Persediaan bahan baku merupakan bahan baku yang masih ada di tangan dan belum diproduksi maka akan dicatat sebagai persediaan bahan baku.

Persediaaan barang dalam proses merupakan bahan baku yang telah diproses menjadi barang jadi namun belum semua proses terselesaikan. Sedangkan persediaan barang jadi merupakan produk yang telah selesai semua prosesnya namun belum terjual sampai akhir periode.

\section{Pengendalian Terhadap Persediaan}

Perusahaan harus selalu mengawasi jumlah persediaan agar tidak terjadi penumpukan persediaan. Ada dua jenis system agar persediaan tercatat secara akurat yaitu : Sistem perpetual dan system periodic. 


\section{Sistem perpetual}

Sistem persediaan perpetual merupakan system persediaan yang mencatat setiap mutasi persediaan, dari pembelian sampai penjualan dan pencatatan dilakukan secara langsung pada saat persediaan ada mutasi. Ciri akuntansu pada system persediaan perpetual yaitu:

1. Jika ada transaksi penambahan persediaan dari pembelian bahan baku atau barang dagangan maka akan dicatat pada sisi debet yaitu akun persediaan bukan akun pembelian.

2. Biaya-biaya yang berhubungan dengan pembelian seperti biaya angkut, diskon pembelian dan retur pembelian akan didebet kedalam akun pesediaan.

3. Harga pokok penjualan didebet dan akun persediaan di sisi kredit untuk mengakui harga pokok penjualan.

Pada system persediaan perpetual terdapat pencatatan mengenai saldo akun persediaan dan akun harga pokok penjualan.

\section{Sistem Periodik}

Sistem persediaan periodic yaitu semua akun pembelian akan dimasukan dalam akun pembelian disisi debit. Untuk jumlah persediaan akan ditentukan secara periodic. Untuk total akun pembelian di akhir periode ditambah biaya persediaan yang ada pada awal periode untuk mengetahui total barang yang tersedia untuk dijual pada periode tersebut. 
. Perbedaan Sistem Pencatatan Perpetual dan Periodik

\begin{tabular}{|c|c|}
\hline SISTEM PERPETUAL & SISTEM PERIODIK \\
\hline \multicolumn{2}{|c|}{ Persediaan Awal, 1 September } \\
\hline $\begin{array}{l}\text { Akun Persediaan } \\
\text { Menunjukkan Barang Yang } \\
\text { Ada Dalam Persediaan } \\
\text { sebesar Rp. 200.000,- }\end{array}$ & $\begin{array}{l}\text { Akun Persediaan } \\
\text { Menunjukkan Barang Yang } \\
\text { Ada Dalam Persediaan } \\
\text { sebesar Rp. 200.000,- }\end{array}$ \\
\hline \multicolumn{2}{|c|}{ Jurnal Untuk Mencatat Pembelian } \\
\hline $\begin{array}{l}\text { Persediaan } \quad 100.000 \\
\text { Utang Dagang } \\
100.000\end{array}$ & $\begin{array}{l}\text { Pembelian } 100.000 \\
\text { Utang Dagang } \\
100.000\end{array}$ \\
\hline \multicolumn{2}{|c|}{ Jurnal Untuk Mencatat Penjualan } \\
\hline $\begin{array}{ll}\text { Piutang Dagang } & 50.000 \\
& \\
\text { Penjualan } & \\
50.000 & \\
\text { HPP } & 45.000 \\
& \\
\quad \text { Persediaan } & \\
45.000 & \end{array}$ & $\begin{array}{cr}\text { Piutang Dagang } & 50.000 \\
\text { Penjualan } & 50.000\end{array}$ \\
\hline
\end{tabular}




\begin{tabular}{|l|lc|}
\hline \multicolumn{2}{|c|}{ Jurnal Penyesuaian Pada Akhir Periode } \\
$\begin{array}{l}\text { Tidak diperlukan jurnal } \\
\text { penyesuaian. Rekening }\end{array}$ & HPP & Persediaan Awal \\
persediaan menunjukkan & 200.000 \\
saldo yang ada pada akhir & HPP & \\
periode yaitu Rp. 255.000,- & He0.000 \\
$\begin{array}{l}\text { (Rp. 200.000 + Rp. 100.000 - } \\
\text { Rp. 45.000) }\end{array}$ & Pembelian \\
& 100.000 \\
& Persediaan Akhir 255.000 \\
& HPP & 255.000 \\
\hline
\end{tabular}

\section{METODE PERHITUNGAN PERSEDIAAN- SISTEM}

\section{PENCATATAN PERPETUAL}

“UD. Kila memiliki data pembelian dan penjualan pada bulan

September 2020 sebagai berikut :

\begin{tabular}{|l|r|c|c|}
\hline Tanggal & Pembelian & Penjualan & Saldo \\
\hline 04 Sept & 500 unit @ Rp. & & 500 unit \\
& 5000 & & \\
\hline 07 Sept & & 300 unit & 200 unit \\
\hline
\end{tabular}




\begin{tabular}{|l|c|c|c|}
\hline 09 Sept & $\begin{array}{c}600 \text { unit @ Rp. } \\
\text { 6.000,- }\end{array}$ & & 800 unit \\
\hline 17 Sept & & 200 unit & 600 unit \\
\hline 21 Sept & & 100 unit & 500 unit \\
\hline 25 Sept & 200 unit @ Rp. & & 700 unit \\
& $6500,-$ & & \\
& & & \\
\hline
\end{tabular}

Soal

1. oktober:

\begin{tabular}{|l|l|l|l|l|l|}
\hline & & \multicolumn{2}{|c|}{ Pembelian } & \multicolumn{2}{c|}{ penjualan } \\
\hline $\begin{array}{l}\text { Tangg } \\
\text { al }\end{array}$ & transaksi & $\begin{array}{l}\text { Kuantita } \\
\text { s }\end{array}$ & $\begin{array}{l}\text { Harg } \\
\text { a } \\
\text { satua } \\
\text { n }\end{array}$ & $\begin{array}{l}\text { Kuantita } \\
\text { s }\end{array}$ & $\begin{array}{l}\text { Harg } \\
\text { a } \\
\text { satua } \\
\text { n }\end{array}$ \\
\hline 1 & Saldo & 100 & $\begin{array}{l}\text { Rp. } \\
520\end{array}$ & & \\
\hline 4 & $\begin{array}{l}\text { Pembelia } \\
\text { n }\end{array}$ & 900 & $\begin{array}{l}\text { Rp. } \\
540\end{array}$ & & \\
\hline 6 & $\begin{array}{l}\text { Penjuala } \\
\text { n }\end{array}$ & & & 400 & $\begin{array}{l}\text { Rp. } \\
800\end{array}$ \\
\hline 8 & Pembelia & 500 & Rp. & & \\
\hline
\end{tabular}




\begin{tabular}{|l|l|l|l|l|l|}
\hline & $\mathrm{n}$ & & 600 & & \\
\hline 11 & $\begin{array}{l}\text { Penjuala } \\
\mathrm{n}\end{array}$ & & & 400 & $\begin{array}{l}\text { Rp. } \\
850\end{array}$ \\
\hline 13 & $\begin{array}{l}\text { Penjuala } \\
\mathrm{n}\end{array}$ & & & 300 & $\begin{array}{l}\text { Rp. } \\
850\end{array}$ \\
\hline
\end{tabular}

Diminta:

Bila menggunakan metode perpetual hitunglah persediaan barang dagangan tanggal 31 Oktober dengan metode FIFO dan Average

\section{Daftar Pustaka}

Keiso, Donald E. Weygandt, Jerry J. Warfield, Terry D. 2007. Akuntansi Intermediate. Penerbit Erlangga. Jakarta.

Martani, Dwi. Dkk. 2016. Akuntansi Keuangan Menengah. Salemba Empat. Jakarta

Niswonger, C. Rollin. Warren, Carls S. Reeve, James M. 1999. Prinsip-Prinsip Akuntansi Edisi 19. Penerbit Erlangga. Jakarta 


\section{DAFTAR PUSTAKA}

Keiso, Donald E. Weygandt, Jerry J. Warfield, Terry D. 2007. Akuntansi Intermediate. Penerbit Erlangga. Jakarta.

Martani, Dwi. Dkk. 2016. Akuntansi Keuangan Menengah. Salemba Empat. Jakarta

Niswonger, C. Rollin. Warren, Carls S. Reeve, James M. 1999. Prinsip-Prinsip Akuntansi Edisi 19. Penerbit Erlangga. Jakarta 


\section{BIODATA PENULIS}

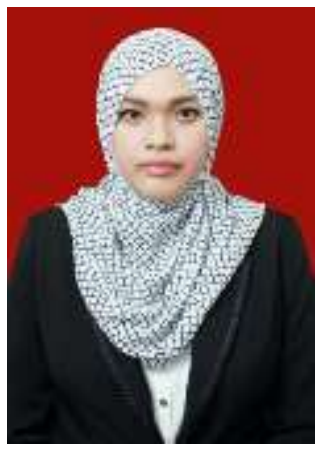

Eny Maryanti, SE, M.A, lahir di Surabaya, $01 \quad$ Maret 1982. Menyelesaikan Studi Strata 2 (S2) pada PPS Magister Akuntansi Universitas Airlangga Surabaya tahun 2012. Pengalaman di bidang pendidikan dimulai sejak tahun 2009-2015 sebagai guru Ekonomi-Akuntansi di Sekolah Alam Insan Mulia Surabaya dan karir sebagai dosen dimulai saat menjadi dosen di Universitas Muhammadiyah Sidoarjo. Pada Tahun 2015 menjadi dosen tetap pada Fakultas Ekonomi dan Bisnis Universitas Muhammadiyah Sidoarjo.

Heri Widodo, SE. M.Si. Ak.CA. Lahir di Malang, 08 September 1973. Menyelesaikan Studi Strata 2 (S2) pada PPS Magister Akuntansi Universitas Airlangga Surabaya tahun 2001 dan menyelesaikan program profesi Universitas Airlangga Surabaya tahun 2012. Saat ini sedang melanjutkan S3 di Universitas Airlangga Surabaya.

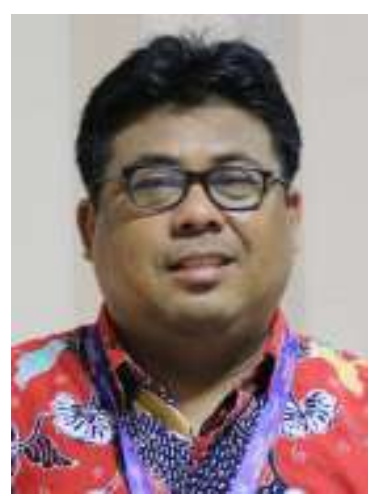

Sampai saat ini menjadi dosen tetap Program Studi Akuntansi Fakultas Bisnis Hukum dan Ilmu Sosial Universitas Muhammadiyah Sidoarjo. 